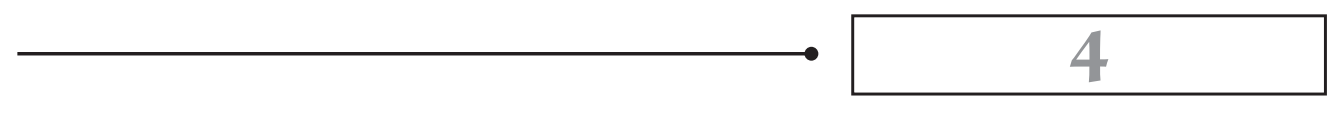

\title{
O POLICENTRISMO DECISÓRIO: OS TRIBUNAIS NA REESTRUTURAÇÃO DA DÍVIDA PÚBLICA ARGENTINA
}

Muitas das características da dispersão institucional a que se submetem as reestruturações da dívida pública instrumentalizada em títulos negociáveis nos mercados financeiros são exibidas pela judicialização de questôes relativas à moratória argentina, declarada em 2001 e sujeita a dois complexos processos de conversão em menos de uma década. Os esforços de negociação, até certo ponto bem sucedidos em assegurar a adesão da quase totalidade dos credores após sucessivas e conturbadas revisões dos acordos, não foram, porém, o bastante para garantir estabilidade aos resultados acordados. $\mathrm{O}$ caso argentino evidencia muitos dos limites da disciplina institucional das renegociações da dívida pública em âmbito internacional. A própria discussão sobre o dever de cooperação internacional, concretizado pelo funcionamento de alguns entes encarregados de conduzir os conflitos segundo princípios reiteradamente afirmados em direção a uma solução consensual, cede lugar ao debate sobre a etapa posterior à conclusão dos acordos, que diz respeito ao recurso a instâncias judiciais que possam revisá-los em eventual contrariedade aos interesses do Estado devedor e de uma maioria qualificada de credores voluntariamente aderentes à proposta de reescalonamento dos pagamentos ou redução dos montantes devidos.

O reconhecimento de eventuais direitos em favor de credores não aderentes é um dos aspectos mais intrincados da reestruturação da dívida mobiliária, em que a multiplicação da quantidade de participantes potencializa as dificuldades de soluçōes coordenadas. A última crise da dívida pública argentina, que estimulou subsequentes manifestações de preocupação da Assembleia Geral das Nações Unidas acerca dos efeitos da ausência de mecanismos de resolução, aponta para a 
participação de outras instâncias institucionais cujos critérios normativos de decisão não dizem necessariamente respeito à vontade majoritária externada em acordos finais obtidos diante de cogitaçóes econômicas e políticas, como se depreende da atuação de tribunais arbitrais internacionais e de cortes nacionais sobre a dívida pública externa de um Estado estrangeiro.

\subsection{A AUSÊNCIA DE UMA MOLDURA JURÍDICA MULTILATERAL PARA A REESTRUTURAÇÃO DA DÍVIDA PÚBLICA}

No dia 9 de setembro de 2014, a Assembleia Geral da Organização das Nações Unidas (ONU) aprovou a resolução 68/304, ${ }^{358}$ referente ao estabelecimento de uma moldura jurídica multilateral para os processos de reestruturação da dívida pública. ${ }^{359}$ Ali se enfatizava a importância de uma solução tempestiva, eficiente, abrangente e duradoura ao problema da dívida de países em desenvolvimento, a qual se concretizaria, segundo o propósito declarado, pela criação de normas que disciplinassem os procedimentos de resolução das crises de endividamento e definissem os espaços legítimos para a conduta dos diversos atores envolvidos. Foram igualmente invocados como necessários novos esforços da comunidade internacional para criar mecanismos de prevenção a crises - mecanismos que pudessem aperfeiçoar a arquitetura financeira internacional vigente, em direção a uma resposta satisfatória tanto aos Estados como ao setor privado, por meio da atuação de instituiçóes internacionais e de negociaçóes intergovernamentais, bem como de outros sujeitos envolvidos nos processos financeiros. O objetivo dessa moldura jurídica, lê-se no documento oficial, é tornar o sistema financeiro internacional mais eficiente, estável e previsível, apto a oferecer condições mais favoráveis ao desenvolvimento sustentável e a um crescimento econômico equitativo, de acordo com as circunstâncias e as prioridades nacionais.

Os termos acima são uma transcrição quase exata do texto da resolução. A linguagem genérica em torno de valores amplamente compartilhados em seus contornos mais vagos, tais como eficiência, estabilidade e desenvolvimento sustentável,

358 NAÇÕES UNIDAS. 2014. Assembleia Geral. Towards the Establishment of a Multilateral Legal Framework for Sovereign Debt Restructuring Processes, A/RES/68/304, $17 / 9 / 2014$.

359 O termo resolução é aqui usado para designar o instrumento formal emitido pela Assembleia Geral, sem implicações sobre seu conteúdo substantivo. A respeito dos efeitos jurídicos das resoluções da Assembleia Geral, vide, mais recentemente, ÖBERG, M. D. The Legal Effects of Resolutions of theUN Security Council and General Assembly in the Jurisprudence of the ICJ. The European Journal of International Law, Glasgow, vol. 16, n. 5, nov. 2005, p. 879-906. 
mas de execução não infrequentemente paralisada por diferentes percepções sobre seus sentidos mais concretos, se bem revela a atualidade e a preocupação internacional com o tema das crises de endividamento, mal denota os conflitos subjacentes. Daí que as formas, as técnicas e os instrumentos de atuação da pretendida moldura jurídica internacional para a reestruturação das dívidas soberanas sejam ainda temas distantes de uma proposta multilateral consolidada. Positivamente, porém, os debates nas Naçôes Unidas recuperaram um tema caro aos países em desenvolvimento: a vulnerabilidade de suas economias à ação desestabilizadora de credores externos e a falta de instrumentos adequados de coordenação de interesses nos procedimentos de renegociação da dívida pública. ${ }^{360}$ Deste modo, longe de resultar de divagações de especialistas, regras para a resolução de crises de endividamento são uma preocupação disseminada e frequente no contexto internacional. A litigância entre Argentina e detentores de títulos públicos que não aderiram à reestruturação procedida pelo país anos antes, pela qual títulos antigos foram trocados por novos com diferentes condiçōes de pagamento, fez com que diversos países pertencentes ao mundo em desenvolvimento, mas não exclusivamente estes, alertassem para os riscos de que os conflitos que envolviam a dívida pública argentina pudesse, por contágio, atingir qualquer um deles. ${ }^{361}$

360 Vide a fundamentação do representante da Bolívia ao apresentar a proposta de resolução: "the recent debt crises and the protracted holdout bondholder litigation against Argentina have led to intensified international debate on the need for a sovereign debt restructuring mechanism that can help improve efficiency, fairness and coordination in restructuring sovereign debt" (NAÇŌES UNIDAS. 2014. Assembleia Geral. 107 ${ }^{\text {th }}$ Plenary Meeting, A/68/PV.107, 9/9/2014, p. 2).

361 O representante da Argentina: "[ $\mathrm{t}$ ] he resolution just adopted is also a faithful reflection of the relevance and urgency that the clear majority of nations of the world assign to a reality that leaves us without protection from the practices of and abuses committed by speculators, given the normative gap in the current international financial system" (NAÇŌES UNIDAS. 2014. Assembleia Geral. 107 ${ }^{\text {th }}$ Plenary Meeting, A/68/PV.107, 9/9/2014, p. 6). O representante da China: " $[\mathrm{t}]$ he international community should take steps to improve international financial governance and to prevent speculative capital from obstructing sovereign debt restructurings so that countries can be more resilient and maintain financial stability (...). China believes that the international financial system needs further reform and that the international regulations governing sovereign debt restructuring should be further improved in order for emerging markets and developing countries to have greater input" (Idem, p. 8). O representante do Brasil: "[a]s we approach the launch of the world's first universal development agenda, the linkage between debt sustainability and sustainable development becomes ever clearer." (Idem, p. 10). O representante do México: "Mexico agrees that we should continue to strengthen the existing framework and that no debt-restructuring process should impose unsustainable burdens on a country or endanger its development and population. In that regard, we reiterate our support to the Government of Argentina regarding the situation that the restructuring of its sovereign debt has led to and our solidarity with countries dealing with similar processes" (Idem, p. 16). 
A proposta de resolução não foi encaminhada por um Estado em particular, mas pelo chamado Grupo dos 77 mais China (G77), uma organização formada em 1964 por países em desenvolvimento para atuar em defesa dos interesses econômicos do hemisfério sul nas Nações Unidas e que conta, atualmente, com 134 países membros - o que expressa a proximidade dos interesses dos Estados do grupo quando confrontados com a hipótese de incapacidade financeira. ${ }^{362}$ Isto não significa, porém, que a institucionalização de procedimentos jurídicos especialmente voltados à reestruturação da dívida pública tenha sido matéria consensual: foram 124 votos favoráveis, 11 contrários e 41 abstençōes. ${ }^{363}$ As manifestações mais frequentes contra a ideia de mecanismos de resolução leem-se em alguns destes votos contrários. Entre eles, os dos Estados Unidos, Reino Unido, Alemanha e Japão - países cuja condição minoritária nessa votação não diminui seu relevo político e econômico. Mas ainda que tenham objetado a proposta de uma solução institucional, tal como expressa nas preocupações do G77, não descartavam outros cenários jurídicos. Tampouco foram desde o início rejeitados os objetivos de conferir respostas mais estáveis aos desafios decorrentes de desequilíbrios da atual arquitetura financeira internacional. Apontou para esta direção o argumento do representante dos Estados Unidos. Primeiro, a crítica: mecanismos aparentemente simplificadores da resolução das crises de endividamento apresentam, em contrapartida, o risco de que se recorra a eles com mais frequência, donde as fontes de financiamento externo se tornariam mais escassas e caras. Logo após, a indicação de uma possibilidade alternativa: Estados emissores de dívida externa já têm adotado soluções negociadas com seus financiadores, as quais se fundamentam em princípios de mercado, em cláusulas contratuais consensuais e no aperfeiçoamento da capacidade de gestão da dívida pública, com o compromisso de adoção de políticas econômicas mais prudentes. ${ }^{364}$ Nesta declaração se encontra resumida a dicotomia recorrente no debate arquitetônico da dívida pública externa, consistente na distinção entre soluções contratuais e institucionais ou organizacionais, estas últimas referentes ao aperfeiçoamento ou à criação de organismos internacionais. Ambas têm evidente configuração jurídica, com elementos e características distintas,

362 Uma análise das atividades do G77 e de sua ampliação pode ser consultada em AHMIA, M. The Collected Documents of the Group of 77. New York: Oxford University Press, 2006, vol. I.

363 Para maior detalhamento, cf. NAÇŌES UNIDAS. 2014. Assembleia Geral. 107th Plenary Meeting, A/68/PV.107, 9/9/2014, p. 4.

364 Ver este argumento na opinião do representante dos Estados Unidos (NAÇÕES UNIDAS. 2014. Assembleia Geral. 107 ${ }^{\text {th }}$ Plenary Meeting, A/68/PV.107, 9/9/2014, p. 5). 
mas que remetem, de forma comum, à constatação de um problema recorrente: os atuais métodos de reestruturação da dívida pública possuem lacunas que requerem correções.

Esta é uma preocupação constante nos debates financeiros das Nações Unidas, o que mostra a posição do tema ao menos em parte da comunidade internacional. A proposta da Resolução 68/304 revisita diversos documentos nos quais as crises de pagamento soberanas foram colocadas em foco. $\mathrm{Na}$ ocasião em que foi apresentada, retomou-se a terceira das Metas de Desenvolvimento do Milênio, o desenvolvimento e a erradicação da pobreza, para cuja concretização se apontou desde o início como necessária a redução do endividamento público. ${ }^{365} \mathrm{~A}$ reforma $\mathrm{da}$ arquitetura financeira internacional por meio de regras adequadas para compor ordenadamente a redução da dívida excessiva de Estados com precariedades orçamentárias, veiculada pelo G77 em 2014, dá sequência às Metas do Milênio e chama à elaboração de um conjunto específico de regras direcionadas à dívida pública como estratégia para enfrentar os desafios de superação do subdesenvolvimento. Igualmente lembradas, ainda, foram as Conferências Internacionais sobre o Financiamento do Desenvolvimento, transcorridas em Monterrey, em 2002, e em Doha, em 2008, que tiveram por resultado, respectivamente, a publicação do Consenso de Monterrey ${ }^{366}$ e da Declaração de Doha, ${ }^{367}$ segundo os quais o alívio da dívida externa tem papel-chave na liberação de recursos para o desenvolvimento. Como tal, deve ser objeto de preocupação de instituiçôes internacionais e de iniciativas voltadas à redução e ao cancelamento do endividamento excessivo, que devem contribuir para uma melhor capacidade de enfrentamento das crises, de forma a explorar melhores alternativas sem, no entanto, preterir de instituições já existentes. ${ }^{368}$

365 Nos termos da Declaração do Milênio das Nações Unidas, "[w]e are also determined to deal comprehensively and effectively with the debt problems of low- and middle-income developing countries, through various national and international measures designed to make their debt sustainable in the long term" (NAÇÕES UNIDAS. 2000. Assembleia Geral. United Nations Millenium Declaration, A/RES/55/2, 18/9/2000, p. 16).

366 NAÇÕES UNIDAS. Conferência Internacional sobre o Financiamento do Desenvolvimento. Monterrey Consensus on Financial Development, 2002.

367 NAÇŌES UNIDAS. Conferência Internacional sobre o Financiamento do Desenvolvimento. Doha Declaration on Financing for Development: Outcome Document of the Follow-Up International Conference on Financing for Development to Review the Implementation of the Monterrey Consensus, A/CONF.212/L.1/Rev. 1, 2008.

368 "External debt relief can play a key role in liberating resources that can then be directed towar$\mathrm{d}$ s activities consistent with attaining sustainable growth and development, and therefore, debt relief measures should, where appropriate, be pursued vigorously and expeditiously, including within the Paris and London Clubs and other relevant forums. Noting the importance of 
O mesmo compromisso de credores e devedores de levar adiante iniciativas para amenizar o elevado volume das obrigações financeiras frente à disponibilidade limitada de recursos, que se viabilizaria por meio da revisão das competências de instituições atualmente existentes, já havia, além disso, sido destacado na Resolução 63/303 da Assembleia Geral, de 2009, resultado da Conferência sobre a Crise Econômica e Financeira Mundial e seu Impacto sobre o Desenvolvimento. Nela se apontou para a necessidade de ação coordenada, igual tratamento a todos os credores e participação dos atores relevantes no processo de decisão. ${ }^{369}$

O tema, como visto, é bastante presente nos debates sobre desenvolvimento travados entre os Estados-membros das Nações Unidas. Para um problema de evidentes implicações econômicas e políticas, cogita-se, nestes documentos, de soluções jurídicas, sejam elas expressas em termos institucionais ou contratuais. Trata-se de um debate fraturado entre diversos interesses conflitantes, dos quais as discussōes em torno da Resolução 68/304 dão apenas uma dimensão pálida. Unem as diversas partes deste tema multifário as preocupações sobre a própria viabilidade de corrigir atuais falhas do sistema financeiro internacional por meio de um sistema que tem sua racionalidade própria (o jurídico), e que deve lidar com uma realidade complexa e fragmentada na qual diversas outras racionalidades, tais

re-establishing financial viability for those developing countries facing unsustainable debt burdens, we welcome initiatives that have been undertaken to reduce outstanding indebtedness and invite further national and international measures in that regard, including, as appropriate, debt cancellation and other arrangements" (NAÇÔES UNIDAS. Conferência Internacional sobre o Financiamento do Desenvolvimento. Monterrey Consensus on Financial Development, 2002, p. 17); "[w] e acknowledge the need to continue to address all relevant issues regarding external debt problems, including through the United Nations, and we will consider ways to explore enhanced approaches of sovereign debt restructuring mechanisms based on existing frameworks and principles, with broad creditors' and debtors' participation and ensuring comparable burden-sharing among creditors, with an important role for the Bretton Woods institutions." (NAÇÕES UNIDAS. Conferência Internacional sobre o Financiamento do Desenvolvimento. Doha Declaration on Financing for Development: Outcome Document of the Follow-Up International Conference on Financing for Development to Review the Implementation of the Monterrey Consensus, A/CONF.212/L.1/Rev. 1, 2008, p. 18)

369 "We call upon States to redouble efforts to honour their commitments regarding debt relief and stress the responsibility of all debtors and creditors on the issue of debt sustainability, and emphasize the importance of equivalent treatment of all creditors (...).We will also explore enhanced approaches to the restructuring of sovereign debt based on existing frameworks and principles, broad creditors' and debtors' participation and comparable burden-sharing among creditors. We will also explore the need and feasibility of a more structured framework for international cooperation in this area." (NAÇÕES UNIDAS. 2009. Assembleia Geral. Outcome of the Conference on the World Financial and Economic Crisis and Its Impact on Development, A/RES/63/303, 9/7/2009, p. 10). 
como a econômica e a política, operam simultaneamente. A mais recente crise financeira argentina, à qual os argumentos favoráveis à adoção da Resolução 68/304 da Assembleia Geral o tempo todo, direta ou indiretamente, remeteram, ilustra as várias facetas do problema internacional da dívida pública, em que os componentes jurídicos são centrais, ainda que não exclusivos.

\subsection{O CASO ARGENTINO}

A moratória argentina declarada em 2001 exemplifica a complexidade da conformação jurídica do problema da dívida pública quando confrontado com a atuação de critérios de solução de conflitos que potencializam as divergências entre as partes. Isto não apenas pelas dificuldades de tradução do fenômeno econômico e político em categorias jurídicas, mas pela própria diversidade das normas aplicáveis. Deste modo, às colisões entre a racionalidade jurídica e a econômica ou política somam-se as fraturas internas dos procedimentos e normas materiais aplicáveis em âmbito internacional, com a participação de instâncias globais e nacionais. Também estas colisões jurídicas intrassistêmicas são bem exemplificadas pelo caso argentino.

Ainda que a Argentina tenha passado, ao longo de sua história, por diversas moratórias, expressamente declaradas ou não, ${ }^{370}$ a cessação de pagamentos da dívida pública em 2001 se destacou pela sua abrangência ${ }^{371}$ e pela amplitude do montante inadimplido. ${ }^{372}$ Após a manifestação oficial de que o cumprimento de obrigações financeiras seria suspenso, seguiu-se a adoção de diversas medidas que, conquanto nem sempre ocorram juntas em casos semelhantes, foram todas perseguidas pela Argentina concomitantemente: ${ }^{373}$ o país recorreu ao auxílio do FMI,

370 De 1824 a 1999, a dívida pública argentina esteve em situação de moratória ou em processo de reestruturação em 25\% do tempo, como estimam Reinhart, Rogoff e Sevastano (Debt Intolerance. In: BRAINARD, W.; PERRY, G. (Ed.) Brookings Paper on Economic Acticity, Washington, D.C.: Brookings Institution Press, vol. 1, 2003, pp. 6-7).

$371 \mathrm{O}$ default se estendeu para mais de 150 espécies de títulos públicos argentinos (MORTIMORE, M.; STANLEY, L. Has Investor Protection Been Rendered Obsolet by the Argentine Crisis? Cepal Review, Santiago, n. 88, abr. 2006, p. 16).

372 A dívida pública argentina representava 63\% do Produto Interno Bruto (PIB) em 2001, e mais de US $\$ 100$ bilhões devidos a detentores domésticos e internacionais dos títulos públicos foram objeto de reestruturação. Desse total, US $\$ 10$ bilhôes eram devidos apenas a investidores dos Estados Unidos (cf. HORNBECK, J. F. Argentina's Sovereign Debt Restructuring. CRS Report for Congress RL32637, Washington, D.C.: Congressional Research Service, 2004).

373 As crises financeiras recentes em países como a Grécia, Portugal e Irlanda conferiram novo impulso ao debate sobre o resgate financeiro ou a reestruturação da dívida a partir da declaração de moratória como cenários alternativos (SCHWARCZ, S. Sovereign Debt Restructuring 
prometeu reformas internas e admitiu a urgência de reestruturar a dívida. Estes três momentos sinalizam um acúmulo de atores, procedimentos e resultados que se sedimentam em questôes jurídicas complexas nas quais é possível distinguir camadas de problemas superpostos, cujas especificidades, no entanto, dificultam que se submetam a soluções uniformemente satisfatórias para o conjunto.

Para compreender o caso, é preciso recorrer a alguns eventos anteriores à moratória. A crise remonta, primeiramente, à adoção de um currency board em 1991. Esta estratégia de política monetária, que consiste na criação de uma caixa de conversão, tem como principal característica a garantia de troca, a uma taxa fixa, da moeda local pela moeda estrangeira lastradora. A credibilidade deste regime advém da existência de reservas externas em quantidade igual ou superior ao valor da moeda local em circulação. Ainda que os currency boards tenham sido mais frequentes nas colônias britânicas do século XIX, em que o risco de destruição e os custos de transporte da moeda metropolitana a territórios distantes requeriam, como medida de estabilização, taxas fixas de conversão das moedas domésticas, eles não são estranhos à experiência latino-americana ${ }^{374}$ e, no início dos anos de 1990, voltaram a ser cogitados nas grandes economias da região. Foi o período em que a adesão a regimes cambiais mais paritários apresentou-se como método de combate à inflação. ${ }^{375}$ Diversos países cogitaram políticas semelhantes. Ainda que não tenha sido levada a cabo no Brasil, em 1992 formulou-se, por exemplo, a ideia de um Conselho da Moeda com as funções de um currency board, cujas emissóes, apelidadas de "brasdólar", serviriam de referencial monetário estável e conviveriam com a moeda fiduciária emitida pelo Banco Central, o cruzeiro, a valores de conversão determinados pelo mercado. ${ }^{376}$ Desde 1991, porém, foi a Argentina que se comprometeu efetivamente com um rígido regime cambial fixo sob o qual permaneceria por mais de uma década.

Options: an Analytical Comparison. Harvard Business Law Review, Cambridge, vol. 2, 2012, p. 96). No caso argentino, eles se mostraram etapas sequenciais.

374 O Brasil, por exemplo adotou caixas de conversão por duas vezes em sua história: em 1906 (Lei 1.575, de 6 de dezembro), como um dos pontos mais importantes do Convênio de Taubaté, e em 1926 (Decreto 5.108, de 18 de dezembro), neste último caso sob a denominação de um caixa de estabilização. O propósito era o controle das flutuaçōes cambiais para a valorização do café. Cf. HADBA, F. A. Caixas de Conversão. Revista de Economia Política, São Paulo, vol. 14, n. 1, jan.-mar. 1994, p. 28-42.

375 Sobre os regimes cambiais na América Latina no período, ver, por todos, CANUTO, O.; HOLlAND, M. Ajustamento Externo e Regimes de Taxa de Câmbio na América Latina. Economia Ensaios, Uberlândia, vol. 15, n. 2, jul. 2001, p. 95-123.

376 RESENDE, A. L. O Conselho da Moeda: um Órgão Emissor Independente. Revista de Economia Política, São Paulo, vol. 12, n. 4, out.-dez. 1992, p. 113-120. 
No bojo do Plano Cavallo, a Lei de Conversibilidade ${ }^{377}$ determinou que o peso argentino fosse fixado em um para um em relação ao dólar americano e que ambas as moedas fossem totalmente conversíveis. $\mathrm{O}$ comitê monetário veio a reduzir consideravelmente as funções do banco central, que passaram a se concentrar, basicamente, em manter níveis adequados de reservas estrangeiras que servissem de lastro sólido a qualquer emissão de moeda doméstica. O problema é que restringir o espaço de elaboração de política monetária poderia reduzir a capacidade que tinha o governo de atender a seus compromissos financeiros caso não houvesse, em contrapartida, o compromisso de apresentar saldos para o pagamento da dívida. Uma limitação monetária de tal magnitude impôs, assim, restrições fiscais, à medida que o governo procurava mostrar aos credores internacionais que tinha condições de solvência. Eventualmente, para formar tais superávits, não se impedia a emissão de dívida, interna ou externa, para financiar o déficit. $\mathrm{O}$ caso argentino exibe, neste aspecto, algumas diferenças do cenário descrito pela literatura econômica como o de uma "constrição estática" do déficit orçamentário: aquelas situações em que a adoção de um currency board, impedindo o financiamento monetário do déficit, bloqueasse também a emissão de dívida. ${ }^{378}$ Não era esse o caso argentino, em que, de início, a dinâmica das finanças públicas foi suficientemente flexível para que acorresse um volume suficiente de superávit primário - o qual, por definição, se destina à satisfação dos compromissos da dívida pública. Exibiu-se uma interessante relação entre o novo regime da moeda e as condiçóes fiscais necessárias para atendê-lo.

Estas relações puderam ser explicadas pelas ideias de dominância fiscal e monetária. Desconsiderada a hipótese de interrupção dos pagamentos da dívida pública, as obrigaçôes financeiras do governo (isto é, suas restriçōes orçamentárias intertemporais) precisam ser satisfeitas, o que pode ocorrer com prevalência da via monetária ou da via fiscal. Numa situação de dominância monetária, o nível de preços é previamente determinado, e a solvência do governo é assegurada pelo caminho fiscal, isto é, pelos ajustes nos fluxos de superávit primário. Num regime de dominância fiscal, por sua vez, é o resultado fiscal que já está previamente estabelecido por elementos externos que não se vinculam exclusivamente à garantia dos níveis necessários de solvência do governo, o que exige, para satisfazer as restrições orçamentárias, ajustes no nível dos preços. ${ }^{379}$ Quando se opera uma política em

377 Lei n. 23.928, de 27 de março de 1991.

${ }^{378}$ FMI. Lessons from the Crisis in Argentina. Washington, D.C.: Policy Development and Review Department, 2003, p. 31.

379 Estas situações são tratadas por Canzoneri, Cumby e Diba como, respectivamente, a de um 
regime de câmbio fixo, o nível doméstico de preços não pode, geralmente, ser ajustado, pois é atrelado à taxa de câmbio para a manutenção da paridade do poder de compra ou de níveis competitivos do valor da moeda. Desta forma, a viabilidade de regimes de câmbio fixo exige que as políticas macroeconômicas operem com dominância monetária, e não fiscal; isto é, que haja flexibilidade para formar quantidades adequadas de superávit primário, de maneira a atestar a capacidade de pagamento dos compromissos financeiros.

A disciplina fiscal aparecia, portanto, como condição indispensável para o sucesso da nova política monetária, e a teoria brevemente exposta acima se mostrou relevante para o caso argentino, em que uma relação mais disciplinada entre receitas e despesas se apresentava como uma exigência para a funcionalidade do currency board. Isto significa que as políticas fiscais deveriam ser prudentes para formar níveis suficientes de superávit primário nos momentos de crescimento da economia, porque em contextos de queda da atividade econômica seria fundamental garantir a solvência do setor público.

O crescimento do endividamento público, após um primeiro período de aparente compromisso político com a necessidade de vincular a política fiscal à estabilidade da moeda comprometia, porém, a estabilidade financeira do currency board. O elevado risco trazido pelo alto nível do endividamento externo, que poderia atingir fortemente a economia argentina no caso de flutuações do capital estrangeiro, somava-se à sobre apreciação do peso, que tinha impacto sobre a competitividade do país e sua balança de pagamentos. Tudo isto compunha um cenário de risco. $\mathrm{O}$ aperfeiçoamento da situação fiscal do país (dependente de condições internas) e a estabilidade internacional (dependente de condições externas) se mostrava, deste modo, um ponto crucial para o sucesso de longo prazo do plano de estabilização. Ainda que a nova política monetária obtivesse sucesso inicial, combinando baixas taxas de inflação com crescimento econômico até $1994,{ }^{380}$ as referidas áreas de

regime ricardiano (em que a política fiscal é regulada de forma a ajustar os superávits primários presentes ou futuros à satisfação das restriçōes orçamentárias do governo para qualquer valor real) e não ricardiano (em que os superávits primários não são determinados pela garantia das condições de solvência, o que ocorre, por exemplo, quando o resultado fiscal é determinado por um processo político exógeno, tal como sua fixação em determinado percentual do PIB). Cf. CANZONERI, M.; CUMBY, R.; DIBA, B. Fiscal Discipline and Exchange Rate Systems. Center for Economic Policy Research Discussion Paper, Londres, n. 1899, maio 1988, p. 2.

380 As taxas médias de inflação foram reduzidas de 84\%, em 1991, para 3,9\%, em 1994. No mesmo período, a taxa média anual de crescimento do PIB foi de 7,7\% (FMI. Lessons from the Crisis in Argentina. Washington, D.C.: Policy Development and Review Department, 2003, p. 7). 
vulnerabilidade se tornaram um problema sério a partir da inversão das tendências internacionais favoráveis vigentes até aquele momento. ${ }^{381}$

Diversas crises externas aumentaram significativamente os custos que decorreriam do abandono do regime monetário vigente, que teria sido mais provável caso ocorresse em cenário de maior estabilidade. Com efeito, após iniciar-se o sistema de constrição monetária, combinada com um abrangente programa de privatizaçōes, reformas administrativas e liberalização do comércio exterior destinados a reduzir o déficit fiscal e aumentar a disponibilidade de reservas, a crise do peso mexicano, em 1995, expôs como a dívida argentina vulnerava a estabilidade econômica. O "choque tequila" imprimiu uma maior tensão sobre zonas de risco do plano: as baixas taxas de juros e a elevada liquidez internacional foram revertidas com o aumento do temor de que o México interrompesse os pagamentos de sua dívida. Economias com características semelhantes - as quais apresentavam, por exemplo, uma real apreciação da taxa de câmbio, que elevava o déficit externo e encarecia as obrigações financeiras, foram contaminadas pelo refugo do crédito. A esta altura já era visível como a evolução positiva do Plano de Conversibilidade nos seus primeiros anos fora dependente de empréstimos do exterior, tendo em vista o crescimento significativo da dívida externa, e como o afrouxamento fiscal das províncias comprometia os esforços no plano federal..$^{382}$

Algum alívio veio do crescimento dos preços internacionais das commodities e da aprovação, no Brasil, do seu plano de estabilização da moeda, o Plano Real, a partir do qual o país vizinho aumentou a demanda por produtos argentinos. Estes fatores fortuitos colaboraram para que houvesse um excedente na balança comercial que serviu para impulsionar o crescimento da economia. No âmbito interno, promoveu-se a reforma do setor bancário e a gestão fiscal foi ainda mais rígida (não sem o protesto dos governadores provinciais), contando-se também com o apoio de agências internacionais multilaterais, que elogiavam a credibilidade da política econômica argentina. ${ }^{383}$

A confiança era, de fato, tão elevada que o país passou pelos choques asiático e russo de 1997 e 1998 sem que a saída de capitais nacionais e estrangeiros fosse comparável à da crise mexicana. Confiava-se no sistema bancário argentino, o

381 HORNBECK, J. F. The Financial Crisis in Argentina. CRS Report for Congress RS21072, Washington, D.C.: Congressional Research Service, 2003.

382 WISE, C. Currency Board da Argentina: Laços que Unem? Revista de Economia Política, São Paulo, vol. 21, n. 3, jul.-set. 2001, p. 175-177.

383 Para uma síntese dos acontecimentos e a respeito do crédito internacional de que gozava a política econômica argentina, cf. PASTOR, M.; WISE, C. From Poster Child to Basket Case. Foreign Affairs, vol. 80, n. 6, nov.-dez. 2001. 
qual, nos termos de um comentarista da época, era um exemplo de sucesso obtido a partir de reformas agressivas e voluntárias. ${ }^{384}$ Os indicadores econômicos positivos sustentavam a permanência da fixação paritária da moeda, que só veio a ser efetivamente abalada pela crise cambial brasileira, em 1999.

Este evento gerou rumores de que o currency board seria flexibilizado. Combinado com as especulaçóes sobre o comportamento das taxas de juros nos Estados Unidos, o resultado foi a insistente negativa do governo e a aposta numa reação ainda mais contundente, que seria a dolarização total da economia. Algumas análises apontam que o governo argentino já estava desde o início do Plano de Conversibilidade a emitir dólares virtuais, como resultado da permissão para depósitos e empréstimos bancários denominados na moeda norte-americana. ${ }^{385}$ A queda das exportações para o mercado brasileiro, porém, atingiu a moeda argentina não pelo sistema financeiro, como se passara nas crises anteriores, mas pela economia real, sobre a qual deveria recair o ajuste. E, com a economia em queda, as medidas de controle fiscal e monetário do início do plano já não caberiam naquele momento. O esforço exigido do país para manter o câmbio fixo se tornava cada vez maior, sobretudo pelas mudanças na base de apoio político do plano. A alternativa restante para promover o ajuste dos preços relativos e diminuir a pressão sobre o peso, que poderia se dar pela via do aumento da produtividade para impulsionar a competitividade do país, não era, assim, apenas uma questão de política econômica, mas de economia política: o Congresso rejeitava as propostas de diminuição de custos da mão-de-obra e de determinados impostos. Além disso, ainda que diversos grupos sociais, principalmente os trabalhadores e produtores rurais, se mostrassem dispostos a apoiar medidas que melhorassem a competitividade da produção argentina, não era uma saída fácil modificar um sistema de controle da moeda que ainda era visto pela população como o responsável pelo combate à hiperinflação. A aposta no currency board se manteve, portanto, diante do choque brasileiro, porém com a necessidade de enfrentar desafios maiores, com custos mais altos, para sua manutenção. Nas eleições de 1999, venceu o candidato Fernando De La Rúa, que não propunha mudanças substanciais no regime de câmbio fixo. ${ }^{386} \mathrm{O}$ déficit em conta

384 CALOMIRIS, C. The IMF's Imprudente Role as Lender of Last Resort. Cato Journal, Washington, D.C., vol. 17, n. 3, 1998, p. 279.

385 LISCHINSKY, B. The Puzzle of Argentina's Debt Problem: Virtual Dollar Creation? In: TEUNISSEN, J. J.; AKKERMAN, A. (Eds.). The Crisis that was not Prevented: Argentina, the IMF, and Globalization. Haia: FONDAD, 2003, p. 81-100.

386 Sobre os aspectos políticos envolvidos, remete-se, novamente, ao texto de WISE, C. Currency Board da Argentina: Laços que Unem? Revista de Economia Política, São Paulo, vol. 21, n. 3, jul.-set. 2001. 
corrente gerava necessidade de empréstimos externos para seu financiamento. Dada a composição da dívida do país com o exterior, o resultado foi uma pressão cada vez maior sobre ela. Alguns anos depois do início de uma recessão econômica que apenas se aprofundava, em 2001 o governo argento interrompeu todos os seus pagamentos. ${ }^{387}$

\subsection{COMPOSIÇÃO E REESTRUTURAÇÃO DA DÍVIDA PÚBLICA ARGENTINA}

Tanto fatores internos como externos conduziram à grave crise argentina do início deste século, de diferentes naturezas. Sob o ponto de vista da economia política interna, que não interessa diretamente a este trabalho, notam-se condicionantes à formulação da política econômica determinadas pela distribuição de forças em dado momento. O cenário externo aponta, ainda, para a vulnerabilidade decorrente de flutuações internacionais, operantes pela via financeira ou da economia real, em um cenário no qual estão presentes maiores canais de contágio. Nenhum destes fatores tem origem em preocupaçōes de índole propriamente jurídica. As formas de organização da dívida pública externa argentina, assim como os mecanismos de resolução de disputas entre o Estado argentino e seus credores, são, no entanto, fundamentais para compreender a evolução da crise. As intersecçõos entre o sistema normativo de organização e desencadeamento dos fatos que ensejaram a crise e os sistemas político e econômico colocados na iminência de lidar com eles podem ser verificadas pela análise das estruturas fundamentais de composição da dívida.

O problema da composição da dívida pública se expressa, sobretudo, em dois termos: a moeda em que é denominada e a maturidade. Em ambos os casos, há diferenças entre as estruturas dos instrumentos de endividamento entre economias avançadas e emergentes. ${ }^{388}$ Para estas últimas, há dificuldades de maior monta em emitir dívida de longo prazo em moeda doméstica. A maior recorrência a dívidas de curto prazo em moeda estrangeira torna estas economias mais suscetíveis a eventos adversos que decorram, por exemplo, de uma desvalorização cambial ou da dificuldade de obter novos financiamentos. Em uma situação de mudanças negativas na percepção do mercado, o crédito do país é afetado e as taxas de juros tornam-se maiores, o que pode se tornar um círculo vicioso: o desequilíbrio fiscal

\footnotetext{
387 Sobre a amplitude do default, HORNBECK, J. F. Argentina's Sovereign Debt Restructuring.

CRS Report for Congress RL32637, Washington, D.C.: Congressional Research Service, 2004. ${ }^{388}$ FMI. Sovereign Debt Structure for Crisis Prevention. Washington, D.C.: FMI, 2004, p. 6.
} 
inicial diminui a margem de manobra para reduzir o impacto da crise, o que potencialmente gera pessimismo nos investidores, que atacam o valor da moeda local e, em consequência, a situação fiscal se deteriora ainda mais. ${ }^{389}$ Porções maiores da dívida pública fixadas em moeda estrangeira tornam, assim, o país mais propenso à incapacidade de pagamento, conforme seus instrumentos de amortizar choques sejam mais ou menos eficazes.

Por sua vez, os prazos de maturidade, definida como a data em que o pagamento é devido, determinam a sensibilidade a fatores contingentes, com o que se suporia ser a dívida de menor tempo de maturidade também menos suscetível à suspensão de pagamentos. ${ }^{390}$ Para países ainda em desenvolvimento, uma dívida pública com esta configuração, ainda que apresente problemas, é uma opção viável para manter as condições de financiamento do déficit, dadas as dificuldades de emissão de dívida de longo prazo se as condições de solvência não são tidas por confiáveis. ${ }^{391}$ Paradoxalmente, no entanto, o excesso de obrigações de curto prazo requer a constante rolagem da dívida, o que nem sempre pode ser feito de maneira tranquila, dados, por exemplo, o aumento nas taxas de juros de curto prazo ou a elevação das restrições orçamentárias. Esta dificuldade de financiar o pagamento da dívida nem sempre indica problemas de solvência do Estado ou outras entidades públicas, podendo decorrer, também, de ausência de liquidez. ${ }^{392}$ Independentemente, porém, do motivo que coloca em dúvida a rolagem, curtas maturidades se associam com uma maior frequência de crises de endividamento. ${ }^{393}$

Apesar de todas estas desvantagens, instrumentos de curto prazo e indexados a uma moeda estrangeira forte são, em contextos específicos, a única opção viável

389 Sobre o "equilíbrio ruim" entre aumentos nas taxas de juros de curto prazo, que conduzem a uma maior probabilidade de default, em decorrência do qual se estimula novo aumento nas taxas de juros, cf. CALVO, G. Servicing the Public Debt: the Role of Expectations. American Economic Review, Pittsburgh, vol. 78, n. 4, set. 1988, p. 647-661; KRUGMAN, P. Balance Sheets, the Transfer Problem and Financial Crisis. International Tax and Public Finance, Nova Iorque, vol. 6, n. 4, nov. 1999, p. 459-472.

390 Para uma crítica da adoção da maturidade de curto prazo como forma de suprir deficiências na confiabilidade do devedor, cf. ALFARO, L.; KANCZUK, F. Sovereign Debt: Indexation and Maturity. Washington: Inter-American Development Bank, 2006, p. 9-11.

391 BARRO, R. J. Optimal Debt Management and Nominal Debt. NBER Working Paper 6197. Cambridge: National Bureau of Economic Research, 1997.

392 Crises de rolagem da dívida por dificuldades de liquidez ocorreram, por exemplo, nos casos mexicano, em 1995, e russo, em 1998. Cf. FMI. Sovereign Debt Structure for Crisis Prevention. Washington, D.C.: FMI, 2004, p. 34.

393 CHANG, R.; VELASCO, A. Banks, Debt Maturity and Financial Crises. Journal of International Economics, Amsterdam, vol. 51, n. 1, jun. 2000, p. 169-194. 
para economias emergentes sustentarem a confiança dos credores. Deste modo, uma interação constante entre os sistemas econômico e jurídico se dá pela tradução, em formas próprias e instrumentos juridicamente válidos, das alternativas economicamente disponíveis para a estruturação da dívida pública.

Era esse o quadro da composição da dívida argentina no período aqui considerado. Nota-se que a dívida pública total era marcadamente vulnerável à conjuntura externa após a desvalorização da moeda local: não apenas a dívida externa do setor público era suscetível a sua vinculação a uma moeda forte, mas também a dívida doméstica fora em grande parte fixada em dólares como garantia contra a desvalorização do peso. Este tipo de operação era possível como resultado do plano de conversibilidade, que permitia a bancos e a fundos de pensão conceder empréstimos indexados. Se, no início, esta autorização indicava um compromisso das instituições de crédito com a fiabilidade do novo regime cambial, no decorrer do tempo se mostrou uma fonte de instabilidade para o cumprimento dos contratos, quando os dólares não puderam ser pagos. Além disso, o cronograma de maturidade da dívida externa era extremamente concentrado, com dificuldades substantivas de financiamento no curto prazo em um cenário no qual se cumulavam juros cada vez maiores e limitações na capacidade de obter divisas pelas transaçôes comerciais internacionais. ${ }^{394}$

As escolhas políticas e econômicas, que afetam os instrumentos de composição da dívida pública (no caso argentino, composta, em volumes relevantes, de obrigações indexadas e de curto prazo), contribuíram, igualmente, para que se formulassem as propostas de reestruturação. Este processo envolveu uma série de decisões sobre os grupos de credores em que recairiam os efeitos da suspensão dos pagamentos. Os instrumentos jurídicos da reestruturação da dívida pública podem ser compreendidos como a formalização e a tentativa de estabilização das decisões a respeito da distribuição dos prejuízos decorrentes dos novos termos de pagamento.

Esta distribuição dos prejuízos se classifica, formalmente, em três categorias: a dívida regularizada, cujo serviço foi continuado; a dívida não reembolsada sem reestruturação, que não é reestruturada e cujo serviço é interrompido; e a dívida não reembolsada a ser reestruturada, que corresponde aos instrumentos financeiros que sofrem alterações formais. ${ }^{395}$ Esta última categoria se divide, ainda, entre duas

${ }^{394}$ LISCHINSKY, B. The Puzzle of Argentina’s Debt Problem: Virtual Dollar Creation?. In: TEUNISSEN, J. J.; AKKERMAN, A. (Eds.). The Crisis that was not Prevented: Argentina, the IMF, and Globalization. Haia: FONDAD, 2003, p. 83.

395 A terminologia não é uniforme. Optou-se pela tradução referente aos termos mais usualmente encontrados, que são, respectivamente, performing debt, non-performing debt not to be restructured e non-performing debt to be restructured. 
subcategorias, correspondentes à reestruturação do principal e a de juros vencidos e vincendos, mas ainda não pagos (PDI, da sigla em inglês para past due interest). Entre estas três classes se distribuíram, inicialmente, os diferentes grupos de credores.

No início das negociações da reestruturação, o governo argentino tentou preservar da redução dos pagamentos algumas classes que considerava mais colaborativas com os esforços do governo, além de apresentarem complexidades maiores para a revisão dos montantes devidos em razão da interpretação de sua precedência no direito ao recebimento dos pagamentos. Assim se situavam os títulos BODEN, emitidos como compensação ao setor financeiro (bancos e depositantes) pela desvalorização do peso, os empréstimos perante instituições financeiras multilaterais como o FMI e o Banco Mundial, operações de crédito garantidas em tentativas anteriores de reestruturação, e os títulos das dívidas provinciais assumidas pelo governo central. ${ }^{396}$ Isto não significa que estes credores não tenham enfrentado reduções nos créditos, tendo em vista que houve perdas substantivas em títulos "precificados" nos anos de 2001 e 2002, mas apenas que estes valores foram mantidos durante a renegociação posterior.

O crédito malparado se identifica, portanto, com as duas segundas categorias, referentes às obrigações inexecutadas. À dívida não reembolsada sem reestruturação pertenciam a dívida bilateral, a dívida com bancos comerciais e os juros incidentes sobre estas obrigações. A seu turno, a dívida não reembolsada a ser restruturada se compunha do principal, isto é, do valor de face dos títulos que não haviam sido pagos desde a moratória em 2001, e de parte do PDI relacionado a estes títulos, calculados até 2004. A dívida para a qual não se apresentou, até aquele momento, proposta de reestruturação, envolvendo o Clube de Paris e bancos comerciais, se aproximava de US \$7 bilhôes, ao passo que os títulos a serem reestruturados valiam US \$104,1 bilhões. Nesta última categoria, o principal era calculado em US $\$ 81,2$ bilhões, e o PDI, em US \$22,9 bilhões. A complexidade do programa de reestruturação da dívida mobiliária era tamanha que abrangia 152 tipos diferentes de títulos. ${ }^{397}$

Conduzir esta proposta ao longo do tempo se mostrou uma tarefa das mais trabalhosas, sobretudo pelas dificuldades de coordenar os interesses dos credores para chegar a uma solução satisfatória à economia argentina e aos recebimentos de ao menos parte dos pagamentos pelos credores de uma dívida que se dizia impagável.

396 A Victory by Default? The Economist, 3 mar. 2005; HORNBECK, J. F. Argentina’s Sovereign Debt Restructuring. CRS Report for Congress RL32637, Washington, D.C.: Congressional Research Service, 2004.

397 ESTADOS UNIDOS DA AMÉRICA. Securities and Exchange Commission. Form 18-K, Annual Report of the Republic of Argentina, Washington, D.C., 30 set. 2011. 
De modo a embaralhar ainda mais um quadro já complexo, a percepção de que era o próprio governo argentino que agia de forma desleal ao não empreender esforços suficientes para evitar o default multiplicou os conflitos. ${ }^{398}$ Da parte dos credores, não havia clareza sobre o tratamento que receberiam e sobre o comportamento do governo, cujo encaminhamento ou para uma solução negociada ou para uma oferta unilateral não era evidente. Já se delineava, porém, que os credores não seriam todos tratados da mesma forma; ao contrário, o cenário da reestruturação era de fragmentação do tratamento jurídico aplicável para mais de uma centena de títulos públicos denominados em sete moedas distintas e submetidos a oito jurisdições territoriais diferentes, com configurações contratuais que não coincidiam.

Antes de iniciar as negociações com os credores privados, o governo argentino buscou, a partir de 2001, um acordo com o FMI para que, refeitas as relaçôes com ele, se pudesse dar maior credibilidade às futuras ofertas aos credores privados e ao Clube de Paris. Esse acordo era necessário para orientar como se reestabeleceriam as condições de crescimento da economia argentina, ao mesmo tempo em que se garantiria superávit suficiente para que a dívida renegociada fosse futuramente paga. Posto em prática o acordo com o Fundo, deu-se sequência à proposta apresentada pelo governo argentino aos detentores dos títulos públicos, em 2003, na reunião do Fórum Econômico Mundial nos Emirados Árabes Unidos. A assim chamada Proposta de Dubai, ainda que não houvesse sido suficientemente detalhada, foi entendida como uma oferta para pagar 25 centavos a cada dólar do valor nominal, sem reconhecimento do PDI - o que representaria um cancelamento que poderia chegar a $90 \%$ do valor atualizado dos títulos. ${ }^{399}$ A seu turno, o governo argentino alegava que a proposta era consistente com o compromisso de 3\% de superávit primário acertado com o Fundo - confirmando a suspeita de que a fixação do resultado acabaria por funcionar como um teto aos esforços fiscais do setor público. A Proposta de Dubai foi objeto de críticas tanto da parte dos credores afetados como do próprio FMI, que passou a sugerir maior boa-fé e uma oferta mais condizente com a real situação argentina, em seu entender capaz de superávits maiores. Nesta etapa começaram a se observar, nos Estados Unidos e sob sua lei interna, os primeiros pedidos judiciais para o sequestro de bens argentinos situados naquele país.

398 PORZECANSKI, A. C. From Rogue Creditors do Rogue Debtors: Implications of Argentina's Default. Chicago Journal of International Law, Chicago, vol. 6, n. 1, jan. 2005, p. 323-4.

399 A insatisfaçao dos governos inglês, italiano e japonês, que representam cerca de $35 \%$ dos votos do FMI, foi formalmente registrada. Cf. HORNBECK, J. F. Argentina's Sovereign Debt Restructuring. CRS Report for Congress RL32637, Washington, D.C.: Congressional Research Service, 2004, p. 7-8. 
A resistência à Proposta de Dubai pelos credores e pelo próprio FMI, também ele credor da Argentina, exigiu novas negociações. A exigência do Fundo era que fosse apresentada uma oferta aceitável a uma grande maioria de detentores de títulos (algo como 80\%), mas determinados grupos de credores já manifestavam, nesta etapa, sua intenção de não aceitar qualquer outra oferta e recorrer à via judicial para executar as obrigações financeiras. A complexa litigância que se formou em torno do tema, observada em perspectiva, pode ter suas origens atribuídas aos problemas de coordenação notados nestas fases iniciais da reestruturação. Algumas das características mais comuns das reestruturações atuais, tais como a assistência do FMI e uma alta adesão de credores, não chegaram a se estabelecer no caso aqui estudado, nesta fase inicial.

O impasse, após idas e vindas, se concluiu com uma oferta unilateral de Buenos Aires protocolada em 10 de junho de 2004 na Comissão de Títulos e Câmbios dos Estados Unidos (SEC, da sigla em inglês para U.S. Securities and Exchange Commission), órgão do governo norte-americano responsável pela regulação dos valores mobiliários. A estratégia argentina dava sinais mais claros de que as conversas com os credores estavam interrompidas. Além de haver suspendido o acordo com o FMI, no âmbito interno foi aprovada a Ley Cerrojo, ${ }^{400}$ que proibia o governo de reabrir, em termos mais vantajosos, o processo de troca dos títulos reestruturados. Agora ou nunca, era a mensagem enviada aos investidores financeiros, esperando-se com isso uma alta adesão à oferta. A conversão se processaria sobre parte do valor de face dos títulos mais o PDI (o que ultrapassava 102 bilhões de dólares), o prazo de resolução seria extenso (ao longo de três anos) e o valor recuperado pelos credores, significativamente pequeno (em torno de $30 \%$ do valor de face atualizado). Apesar da proibição legal de futuras ofertas, $24 \%$ dos credores recusaram a proposta e passaram a compor a classe residual dos não aderentes, também conhecidos como holdouts. ${ }^{401}$

A baixa adesão à oferta de 2005 impediu que se superasse a fase da reestruturação. Os títulos em litígio mais a dívida com o Clube de Paris e com o FMI exigiram novas medidas, como o pagamento total das obrigaçôes com o Fundo. Restava, porém, a dívida com os países do Clube de Paris, cujo adimplemento fora prometido para 2010, e a disputa com os credores resistentes - com os quais, apesar

${ }^{400}$ Lei 26.017, de 9 de fevereiro de 2005.

401 As informações podem ser encontradas em HORNBECK, J. F. Argentina's Defaulted Sovereign Debt: Dealing with the "Holdouts". CRS Report for Congress R41029, Washington, D.C.: Congressional Research Service, 2013. 
do discurso de enfrentamento assumido pelo governo argentino, alguma tentativa de pacificação deveria ocorrer. Resolver esta parte importante da dívida pública era uma condição para o retorno da Argentina aos mercados financeiros internacionais e para retomar as possibilidades mais amplas de financiamento por meio de operações de crédito externo, então basicamente restritas à venda direta de títulos ao governo da Venezuela. Com reservas internacionais recompostas, crescimento econômico e saldo comercial positivo, as condiçôes para reestruturar a parte da dívida ainda em disputa eram mais favoráveis. Em 2009 foi suspensa a parte da Ley Cerrojo que impedia novas ofertas de troca dos títulos e a nova proposta foi oficialmente apresentada à SEC no final daquele ano. Em meados de 2010 iniciou-se a segunda reestruturação da década, estimando-se que, caso se contasse com $60 \%$ de adesão nesta fase, $90 \%$ da dívida não reembolsada desde a moratória de 2001 teria sido reestruturada. Este patamar seria suficiente para que o país exibisse novamente sua credibilidade, caso, no entanto, o procedimento seguido tivesse sido o usual, por meio de negociações. Como o caso envolvia ofertas unilaterais, mesmo uma adesão maior do que aquela tida como necessária (agora 91,3\% dos credores haviam aderido) não foi suficiente para afirmar a capacidade de pagamento do país e evitar novas suspensões futuras, sobretudo porque havia muitas dúvidas sobre o resultado jurídico da disputa com o resíduo de credores resistentes às ofertas governamentais.

É frequente que esses credores atuem em defesa de seus interesses por meio de pedidos judiciais que determinem a execução do patrimônio do Estado localizado no exterior, e não foi diferente no caso argentino. No entanto, o regime jurídico da dívida pública em disputas internacionais é fragmentado, com conceitos incertos e superposição de jurisdições. Saber operar suas inconsistências pode ser uma vantagem relativa para alguma das partes do processo, como o foi para os assim chamados fundos abutres, cuja denominação em inglês, vulture funds, ironiza o comportamento predatório de investidores especializados em adquirir títulos com valor real significativamente menor do que o valor nominal (por assim dizer, carcaças financeiras) e, em seguida, pleitear o pagamento integral. Estes são fundos de cobertura ou de investimento (hedge funds ou private equity funds, normalmente) cujo comportamento estratégico, de caráter especulativo e de alto risco, consiste inicialmente, entre outras práticas, em não subscrever as ofertas de troca de títulos públicos. Ameaçando o sucesso da reestruturação, sua adesão pode ser recompensada com prêmios maiores. Ocorre, também, que recorram à litigância judicial para obter reembolso integral do valor ao par dos títulos (isto é, pelo seu valor de face), a despeito da maioria dos outros credores ter aceitado cancelamentos 
significativos. Conquanto não seja novo e já tenha sido enfrentado em diferentes foros com respostas distintas, o comportamento não cooperativo dos credores resistentes expõe desafios constantes das reestruturações: a coordenação de interesses de todas as partes, a necessidade da ação coletiva e os incentivos institucionais para a cooperaçãa.

\subsection{A ATUAÇÃO JUDICIAL DOS CREDORES RESISTENTES}

A judicialização promovida por credores residuais da Argentina contra aquele Estado em diferentes foros internacionais e nacionais permite, isolando algumas particularidades que incidem apenas no caso, compreender o problema da reestruturação da dívida com credores privados em duas instâncias de atuação: os tribunais arbitrais internacionais e a litigância em cortes internas. Os credores privados que resistiram às ofertas argentinas recorreram, de um lado, à disputa arbitral perante o Centro Internacional para a Arbitragem de Disputas sobre Investimentos (ICSID, do inglês International Centre for Settlement of Investiment Disputes), que funciona sob o Banco Mundial, e, de outro, à Corte de Nova Iorque, cuja análise evidencia o cenário de desarticulação entre os locais de solução de controvérsias relativas à dívida pública externa.

\subsubsection{A arbitragem internacional}

Cortes arbitrais têm sido chamadas recentemente a enfrentar a questão da inexecução da dívida pública e sua exigibilidade nos termos inicialmente pactuados, particularmente pelas conexões que se estabelecem entre negócios com títulos públicos e os investimentos estrangeiros. O ICSID assumiu alguma importância como locus de solução das controvérsias da dívida pública pela via arbitral. A primeira reclamação a respeito do mais recente default argentino foi movida por cerca de 170.000 credores italianos em 2006, pleiteando por volta de cinco bilhōes e meio de dólares em compensações. ${ }^{402} \mathrm{O}$ pedido, posteriormente renomeado como o caso Abaclat, ${ }^{403}$ serve, ainda que não decidido no mérito, de importante precedente sobre a competência do ICSID em matéria de proteção de credores de títulos públicos, pois o inadimplemento argentino teria violado acordo bilateral de investimentos (BIT, para bilateral investment treaty).

${ }^{402}$ MANDER, B. New Tack on Argentina Debt. Financial Times, 28/09/2006.

${ }^{403}$ Abaclat and Others v. the Argentine Republic, ICSID, Case n. ARB/07/5, Decision on Jurisdiction and Admissibility, 4/08/2011. 
Como o caso mais importante sobre arbitragem internacional de títulos da dívida pública, os complexos impactos do Abaclat na maneira como os Estados negociam alterações nos pagamentos de suas obrigações financeiras, ainda que não possam ser completamente previstos, apreciados, permite avaliar alguns aspectos mais relevantes a propósito de sua relação com a preferência por soluções negociadas e coordenadas entre as partes. Os fatos que conduziram à disputa em curso serão expostos conforme elaborado pela decisão do ICSID na decisão em que afirmou sua competência sobre a matéria disputada. ${ }^{404}$

Muito da dívida externa argentina se compunha de títulos em mãos de investidores italianos. ${ }^{405}$ Seguindo uma resolução da Associação de Bancos Italianos, oito grandes instituições ${ }^{406}$ formaram a Associazione per la Tutela degli Investitori in Titoli Argentini, também conhecida por Task Force Argentina (TFA). Esta associação, organizada sob a lei civil italiana, teve por finalidade representar seus membros nas negociações com o governo de Buenos Aires. ${ }^{407}$ Algum tempo depois, em janeiro de 2004, a TFA se associou ao Comitê Global de Detentores de Títulos Argentinos (GCAB, da sigla em inglês para Global Committee of Argentina Bondholders), fundado por dois outros grandes grupos, a Argentine Bond Restructuring Agency e o Argentine Bondholders Committee, além de dois outros bancos japoneses (Tokyo-Mitsubishi e Shinsei). ${ }^{408} \mathrm{O}$ propósito do GCAB é coordenar a ação de seus membros diante das propostas argentinas.

Após a divulgação da primeira oferta de troca em 2004, abriu-se a oferta em 14 de janeiro de 2005 , encerrada em 25 de fevereiro do mesmo ano. ${ }^{409}$ De acordo com os termos de reestruturação, algumas séries de títulos cujo pagamento havia sido suspenso seriam convertidas sob condiçôes diferentes, como já se viu, proposta

${ }^{404}$ Abaclat and Others v. the Argentine Republic, ICSID, Case n. ARB/07/5, Decision on Jurisdiction and Admissibility, 4/08/2011.

405 Aproximadamente US \$13,5 bilhões de um total de US $\$ 137$ bilhões. Os detentores italianos dos títulos argentinos eram aproximadamente 600.000 pessoas (Abaclat and Others v. the Argentine Republic, ICSID, Case n. ARB/07/5, Decision on Jurisdiction and Admissibility, 4/08/2011, \$\$ 63-64).

${ }^{406}$ Banca Antonveneta, Banca Intensa, Banca Sella, BNL, Iccrea Banca, Monte dei Paschi di Siena, San Paolo e UniCredito (Abaclat and Others v. the Argentine Republic, ICSID, Case n. ARB/07/5, Decision on Jurisdiction and Admissibility, 4/08/2011, \$ 65).

${ }^{407}$ Informaçoes sobre o estatuto desta associação estão disponíveis em http://www.tfargentina.it/ chisiamo.php.

${ }^{408}$ Abaclat and Others v. the Argentine Republic, ICSID, Case n. ARB/07/5, Decision on Jurisdiction and Admissibility, 4/8/2011, $\$ 72$.

409 Registrada como Form 18-K/A, U.S. Securities and Exchange Commission. 
que $76,15 \%$ dos detentores de títulos haviam aceitado, ${ }^{410}$ sem que entre eles se encontrassem os membros do TFA, que, em 2006, acusaram o governo de ter agido unilateralmente e de má fé. ${ }^{411}$

A alegação era de que o processo de reestruturação representara a expropriação de investimentos italianos, além da falta de tratamento justo e equitativo a estes credores, que se encontrariam em situação mais desfavorável do que outros, em violação ao acordo de investimentos existente entre Argentina e Itália, firmado em 22 de maio de 1990. Na falta de solução amigável, o TFA obteve o mandato de seus membros para iniciar procedimento arbitral no ICSID. Em abril de 2010, o governo argentino promoveu outra oferta de troca, oferecendo novos títulos para afastar a causa do litígio, propondo, em alguns casos, até pagamentos em espécie. ${ }^{412}$ Alguns credores entenderam que esta segunda reestruturação dos títulos não cumpridos constituía nova medida unilateral, à medida que o crédito não seria pago em sua totalidade, mas ao final aderiram à oferta e retiraram-se do pedido de arbitragem. ${ }^{413}$ Não foi o que todos fizeram, e alguns ainda insistiram na atuação do ICSID para resolver a controvérsia. O número de reclamantes diminuiu, porém, para sessenta mil.414

Ainda que não haja decisão de mérito do caso em questão, fundadas as alegações no argumento de ausência de tratamento justo e equitativo e de violação ao acordo entre ambos os países envolvidos, o Tribunal firmou importante precedente quanto à própria competência sobre disputas de investimentos relativos a títulos da dívida pública. Esta decisão é singular em muitos sentidos. É pertinente, nesta fase do trabalho, considerar a particularidade de muitos dos argumentos utilizados pelo Tribunal para vislumbrar suas implicações sobre os processos de reestruturação da dívida pública. Alguns dos aspectos processuais não serão estendidos, ainda que tenham relevância, tal como a reclamação em massa em procedimentos arbitrais, dada a imensa quantidade de autores. ${ }^{415}$

410 Abaclat and Others v. the Argentine Republic, ICSID, Case n. ARB/07/5, Decision on Jurisdiction and Admissibility, 4/8/2011, $\$ 80$.

411 Abaclat and Others v. the Argentine Republic, ICSID, Case n. ARB/07/5, Decision on Jurisdiction and Admissibility, 4/8/2011, $\$ 84$.

412 Exchange Offer Prospectus (Exh. C-999B).

413 Abaclat and Others v. the Argentine Republic, ICSID, Case n. ARB/07/5, Decision on Jurisdiction and Admissibility, 4/8/2011, \$92-7.

414 Abaclat and Others v. the Argentine Republic, ICSID, Case n. ARB/07/5, Decision on Jurisdiction and Admissibility, 4/8/2011, \$216.

415 Para uma análise desta questão, cf. DONOVAN, D. Case Comment: Abaclat and Others $v$. Argentine Republic as a Collective Claims Proceeding. ICSID Review, Washington, D.C., v. 27, 
Um dos pontos mais pertinentes e controvertidos do caso Abaclat é o conceito de investimento estrangeiro, e sua extensão à aquisição de títulos da dívida pública. Sobre este conceito é que o ICSID afirmou sua competência para decidir a questão. Assim, para que se reconheça a legitimidade dos credores italianos para obter uma decisão arbitral é preciso que tenha havido um rompimento do acordo bilateral relevante. De fato, a proliferação dos BITs a partir da década de 1980 conferiu ao ICSID posição proeminente na solução de controvérsias entre Estados e investidores estrangeiros. O artigo 25(1) da Convenção de Washington confere-lhe competência ratione materiae para qualquer disputa de natureza jurídica diretamente decorrente de um investimento entre um Estado e um nacional de outro Estado. ${ }^{416}$ Deve haver, no entanto, consentimento das partes para submeter a disputa à jurisdição do ICSID, que fica confinada, portanto, dentro destes limites: a controvérsia deve ser originária de uma violação da proteção do investimento, e as partes devem concordar em submetê-la ao procedimento arbitral.

Ao passo que o único requisito formal do consentimento é que ele seja escrito, há várias formas de manifestá-lo. Estas formas podem ser classificadas em contratuais e não contratuais. Quanto às contratuais, o Estado manifesta diretamente sua concordância com a arbitragem em um instrumento escrito cujo teor é pactuado com o investidor, ao passo que as formas não contratuais referem-se às situações em que o consentimento estatal é determinado em lei, em acordo bilateral ou outro acordo. ${ }^{417} \mathrm{O}$ BIT entre Argentina e Itália autoriza o recurso à arbitragem após consultas amigáveis e o recurso às vias internas de solução de conflitos. ${ }^{418}$ A disputa

n. 2, 2012, p. 261-27; STRONG, S. Mass Procedures as a Form of "Regulatory Arbitration" Abaclat v. Argentine Republic and the International Investment Regime. The Journal of Corporation Law, Iowa, v. 38, n. 2, 2013.

416 No original, " $[\mathrm{t}]$ he jurisdiction of the Centre shall extend to any legal dispute arising directly out of an investment, between a Contracting State (or any constituent subdivision or agency of a Contracting State designated to the Centre by that State) and a national of another Contracting State, which the parties to the dispute consent in writing to submit to the Centre. When the parties have given their consent, no party may with- draw its consent unilaterally" (ICSID. Convention on the Settlement of Investment Disputes between States and Nationals of Other States (1965). Washington, D.C.: ICSID, 2016, p. 18).

417 REED, L.; PAULSON, J.; BLACKABY, N. Guide to ICSID Arbitration. Haia: Kluwer Law International, 2011, p. 35.

418 O artigo 8(3) do acordo estabelece que "[o]ve tra una Parte Contraente ed investitori sussista ancora controversia, dopo trascorso un periodo di 18 mesi dalla notifica di inizio di una azione avanti le magistrature nazionali indicate al paragrafo 2 , tale controversia potrà essere sottoposta ad arbitrato internazionale" (Accordo fra la Repubblica Italiana e la Repubblica Argentina sulla Promozione e Protezione degli Investimenti, 22/5/1992) Não há tradução oficial para o inglês. 
pode ser iniciada no ICSID ou num tribunal ad hoc que siga as regras da UNCITRAL (United Nations Commission on International Trade Law). ${ }^{419}$ Dada certa imprecisão sobre as formas de manifestação do consentimento escrito, o próprio BIT, prevendo a via arbitral, pode ser entendido como uma oferta do Estado para resolver a disputa por este caminho; considera-se a proposta aceita quando a outra parte efetivamente solicita a instauração dos procedimentos perante o Centro. ${ }^{420}$ Sendo, no caso Abaclat, inequívoco que ambas as partes contratantes concordaram com esta maneira de resolver eventuais controvérsias, a questão da competência gira em torno do próprio conceito de investimento: as reclamações a respeito do descumprimento do estabelecido nos títulos argentinos fica sujeita às regras de proteção dos investidores estrangeiros?

A Argentina tentou, nesta fase, encerrar a disputa afirmando que não houvera violação do acordo bilateral. As alegaçôes italianas diriam despeito a disputas surgidas de violaçôes contratuais (isto é, do firmado nos títulos públicos), e não do acordo. ${ }^{421}$ Este argumento suscita uma importante distinção entre disputas contratuais e outras originadas do rompimento de tratados. Os credores italianos apenas estariam protegidos se os danos sofridos houvessem se originado de violações do acordo bilateral ou se este acordo contivesse cláusulas guarda-chuva (umbrella clauses) que permitissem uma interpretação ampla o suficiente para abarcar outras obrigações contraídas pelo Estado. ${ }^{422}$ Estas cláusulas de aplicação geral não estão contidas no BIT Argentina-Itália, portanto a discussão está centrada em ter havido rompimento de um contrato ou do tratado em si.

$\mathrm{O}$ Centro considerou que o default argentino representou uma quebra de contratos, mas não exclusivamente. A oferta de troca não se resumiu a este tipo de violação: a modificação unilateral dos pagamentos valeu-se de um ato de soberania: "o que a Argentina fez, fez baseada no seu poder soberano; [a oferta] não é baseada nem deriva de um argumento ou mecanismo contratual". ${ }^{423}$ Em outras

419 Artigo 5(a)(b), Accordo fra la Repubblica Italiana e la Repubblica Argentina sulla Promozione e Protezione degli Investimenti, 22/5/1992.

420 Abaclat and Others v. the Argentine Republic, ICSID, Case n. ARB/07/5, Decision on Jurisdiction and Admissibility, 4/8/2011, \$258.

421 Abaclat and Others v. the Argentine Republic, ICSID, Case n. ARB/07/5, Decision on Jurisdiction and Admissibility, 4/8/2011, $\$ 316$.

422 YANNACA-SMALL, K. Interpretation of the Umbrella Clause in Investment Agreements. OECD Working Papers on International Investment, Washington, D.C., n. 3, 2006, p. 1-29.

423 Abaclat and Others v. the Argentine Republic, ICSID, Case n. ARB/07/5, Decision on Jurisdiction and Admissibility, 4/8/2011, $\$$ 323. No original, "what Argentina did, it did 
palavras, ao reestruturar sua dívida externa, o governo argentino acabaria por violar contratos, mas o fazia usando de seu poder soberano como um Estado que alegava insolvência. As reclamações não se fundavam, portanto, apenas em princípios obrigacionais. O ICSID reforçou a perspectiva de que as obrigaçôes originadas da dívida pública, conquanto não sejam matéria de exclusiva soberania nacional, como afirmava a Doutrina Drago, apresentam características próprias, que não permitem dizer de um exclusivo regime jurídico privado. A consequência desta abordagem é que a disputa não versando, prima facie, sobre inadimplementos contratuais, ela estaria provavelmente relacionada a uma violação do acordo bilateral. A discussão que o Centro passou a travar, portanto, foi a própria noção de investimento, nos termos do acordo.

$\mathrm{Na}$ tradução não oficial do BIT Argentina-Itália, investimento é definido como qualquer entrega de ativos investidos ou reinvestidos por indivíduos ou empresas de uma parte ao território de outra parte, em conformidade com a ordem jurídica desta última. ${ }^{424} \mathrm{~A}$ definição é, em certa medida, tautológica, mas a seguir o acordo prevê uma lista não limitativa de exemplos, dentre os quais a letra "c" faz referência a "títulos, instrumentos financeiros públicos ou privados ou quaisquer outros direitos a prestações e serviços que tenham valor econômico, incluindo receitas capitalizadas". 425

Apesar do teor do acordo, a Argentina apoiou-se em três argumentos para sustentar que a aplicação de recursos em títulos da dívida não constituía investimentos: i) a definição estabelecida no caso Salini não havia sido, no caso, satisfeita; ii) não houve transferência de ativos para o território argentino; e iii) a aquisição dos títulos não havia sido feita em conformidade com a lei argentina.

based on its sovereign power; it is neither based on nor does it derive from any contractual argument or mechanism".

${ }^{424}$ Como citado em Abaclat and Others v. the Argentine Republic, ICSID, Case n. ARB/07/5, Decision on Jurisdiction and Admissibility, 4/8/2011, \$336, o artigo 1(1) do BIT define que investimento é "any conferment of asset invested or reinvested by an individual or corporation of one Contracting Party in the territory of the other Contracting Party, in compliance with the laws and regulations of the latter party". No original em italiano, "per investimento si intende, conformemente all'ordinamento giuridico del Paese ricevente ed indipendentemente dalla forma giuridica prescelta o da qualsiasi altro ordinamento giuridico di riferimento, ogni conferimento o bene investito o reinvestito da persona fisica o giuridica di una Parte Contraente nel territorio dell'altra, in conformità alle leggi e regolamenti di quest'ultima".

${ }^{425}$ Abaclat and Others v. the Argentine Republic, ICSID, Case n. ARB/07/5, Decision on Jurisdiction and Admissibility, 4/8/2011, \$336. No original, "obbligazioni, titoli pubblici o privati o qualsiasi altro diritto per prestazioni o servizi che abbiano un valore economico, come altresì redditi capitalizzati”. 
O precedente citado é o caso Salini, decidido pelo ICSID em 2004. Aí se fixaram alguns critérios substantivos para a delimitação conceitual de investimentos, tais como a exigência de contribuições da aplicação aos investidores, certa duração do contrato e a contribuição ao desenvolvimento econômico do Estado recipiente. ${ }^{426} \mathrm{O}$ segundo argumento, qual seja, o de que não havia suficiente conexão física e jurídica com seu país, se apoiava na circunstância de não terem os credores italianos transferido dinheiro ao território da Argentina, tendo comprado seus títulos em bancos italianos. ${ }^{427}$ A conexão territorial seria, pois, remota. Finalmente, aduziu-se que algumas das provisões da venda dos títulos promovida pelos referidos bancos seriam ilícitas, tendo violado a boa-fé contratual e diversas normas europeias que restringem a venda de títulos públicos no varejo. ${ }^{428}$

O ICSID, no entanto, alterou, no caso Abaclat, a linha de atuação que havia estabelecido no caso Salini. Para definir um ato como investimento, os critérios materiais anteriores foram substituídos por um teste de duas etapas: para ser considerado como tal, é preciso que um investimento seja compatível com a definição fornecida pelo acordo aplicável e que esta definição corresponda ao significado contido na Convenção do ICSID. ${ }^{429}$ Consequentemente, tanto o consentimento expresso pelo Estado quanto a competência do Centro devem ser considerados. Esta definição é mais ampla que aquela trazida no caso Salini, fixando-se a competência para solução de controvérsias no consenso expresso pelas partes de que determinado ato será considerado, para os efeitos da proteção conferida pelo BIT, um investimento. Isto se corrobora com a disposição ampla conferida pela Convenção do ICSID ao tema, que não adota uma formulação restritiva e permite que as partes tenham um relevante espaço de negociação para inclusão de determinadas categorias no escopo de aplicação do acordo. Finalmente, a letra "c" do acordo entre Argentina e Itália prevê expressamente diversas modalidades de instrumentos financeiros os quais, ainda que não tenham as características apontadas no caso Salini, passaram a ser protegidos como investimentos por convenção das partes. ${ }^{430}$

${ }^{426}$ Salini Construttori S.p.A. and Italstrade v. Kingdom of Morocco, ICSID, Case n. $\mathrm{ARB} / 00 / 4$, Decision on Jurisdiction, 23/7/2001, $\$ 52$.

${ }^{427}$ Abaclat and Others v. the Argentine Republic, ICSID, Case n. ARB/07/5, Decision on Jurisdiction and Admissibility, 4/08/2011, \$341.

${ }^{428}$ Abaclat and Others v. the Argentine Republic, ICSID, Case n. ARB/07/5, Decision on Jurisdiction and Admissibility, 4/08/2011\$341(iii).

429 Abaclat and Others v. the Argentine Republic, ICSID, Case n. ARB/07/5, Decision on Jurisdiction and Admissibility, 4/08/2011, $\$ 344$.

${ }^{430}$ Abaclat and Others v. the Argentine Republic, ICSID, Case n. ARB/07/5, Decision on Jurisdiction and Admissibility, 4/08/2011, $\$ 355$. 
Estas considerações permitiram ao Centro afirmar que a disputa em torno do inadimplemento dos títulos públicos argentinos pode se submeter às garantias do acordo bilateral aplicável, compatível tanto com este instrumento específico como com a Convenção de Washington, tomando em conta sua finalidade, que é a proteção de investimentos privados, mesmo que as restrições previstas pelo caso Salini não tivessem sido estritamente satisfeitas.

Os outros argumentos argentinos também foram discutidos pelo Centro. A propósito da territorialidade, a pergunta a ser feita era se recursos financeiros aplicados pelos credores italianos foram ou não colocados à disposição da Argentina de maneira a sustentar suas políticas econômicas e estratégias de desenvolvimento. ${ }^{431}$ Sendo este o critério, considerou-se claro que o financiamento atraído pela venda dos títulos havia sido útil ao Estado que os emitira, a despeito da ausência de rigorosa conexão com seu território.

Em síntese, os padrōes estabelecidos no caso Abaclat, ainda que não haja decisão de mérito, representam uma perspectiva de proteção ainda sem paralelos dos investidores estrangeiros que adquirem títulos de governos estrangeiros. Este cenário permite avaliar algumas de suas consequências para a maneira como Estados em crise passariam a reestruturar suas dívidas, havendo a perspectiva de uma decisão favorável aos credores pela via da arbitragem internacional.

A arbitragem internacional de conflitos originados do default do Estado tem, porém, precedentes relevantes. Também em relação a estes o caso Abaclat apresenta particularidades e pode ser considerado uma ampliação das proteções até então previstas para os detentores de títulos públicos. Não é nova, porém, a ideia de que a aquisição destes instrumentos financeiros pode ser entendida como modalidade de investimento e de que os credores atingidos dispõem de proteções no sistema internacional. O caso o Fedax v. Venezuela já havia tratado especificamente da proteção dos títulos públicos sob um acordo bilateral de investimentos. ${ }^{432}$ Este caso tem mais proximidade com a proteção que os detentores de títulos italianos têm procurado contra a Argentina, uma vez que foi o primeiro em que a competência do ICSID foi acionada em razão de um litígio sobre a qualificação de certas transaçôes financeiras como investimentos.

Em breve relato dos fatos, certos instrumentos de dívida em dólares norte-americanos foram emitidos pelo governo da Venezuela e atribuídos, por endosso,

\footnotetext{
431 Abaclat and Others v. the Argentine Republic, ICSID, Case n. ARB/07/5, Decision on Jurisdiction and Admissibility, 4/08/2011, $\$ 374$.

${ }^{432}$ Fedax NV v. Republic of Venezuela, ICSID, Case n. ARB/96/3, 9/3/1998.
} 
à Fedax, uma empresa constituída em Curaçao, território da Holanda. Alegava-se que a Venezuela não pagará nem o principal nem os juros das notas promissórias, o que não havia sido contestado pelo país emitente. A decisão do ICSID sobre a jurisdição teve de lidar com a situação legal de notas promissórias emitidas por um Estado soberano sob a proteção de tratados internacionais. O caso Fedax teve influência decisiva sobre a forma como o Centro compreende um investimento. ${ }^{433}$ Ele deu três passos para analisar o caso: decidir se um instrumento financeiro (público ou privado) pode ser protegido como um investimento exige o exame da Convenção do ICSID, do BIT relevante e da distinção de transações comerciais comuns.

Quanto à Convenção, afirmou-se que, segundo seus propósitos, deixa-se às partes significativa margem de autonomia para determinar quais as questôes passíveis de arbitragem. ${ }^{434} \mathrm{O}$ artigo $25(1)$ possibilita uma definição ampla de investimentos, que é, em última análise, definida pelas partes contratantes. Na segunda etapa, foi examinado se o BIT aplicável fazia referência à anuência necessária para submeter a controvérsia a uma decisão arbitral no ICSID. Com o Centro estabelecendo uma ampla noção de investimento, concluiu-se que as notas promissórias eram abrangidas por ele. ${ }^{435}$ Por último, mas não menos importante, foi necessário classificar as notas promissórias no âmbito de operações comerciais comuns (não abrangidas pela proteção da ICSID) ou sob uma disputa de investimento. O Centro fez uma distinção entre arranjos de curto prazo (capitais voláteis) e os de longa duração, indicando que a aquisição de tais instrumentos não visava lucro imediato. Por outro lado, eles envolveram certas duração e regularidade de ganhos, representando também decisões financeiras importantes para o desenvolvimento do Estado receptor. ${ }^{436}$ Também sob este último teste as transações seriam consideradas investimentos. A alegação do Estado de que os investimentos não foram feitos "no território” da República da Venezuela foi desconsiderada pelo ICSID, já que os fundos foram efetivamente transferidos para o país e disponibilizados para ele.

O caso Fedax reforçou comentários acadêmicos anteriores sobre a natureza dos investimentos, que também tinham sido estabelecidos no caso Salini: contribuição para o investidor, duração, risco e contribuição para o desenvolvimento do

433 "Since promissory notes are evidence of a loan and a rather typical financial and credit instrument, there is nothing to prevent their purchase from qualifying as an investment under the ICSID Convention in the circumstances of a particular case such as this" (Fedax v. Venezuela, ICSID Case n. ARB/96/3, Decision on Jurisdiction, jul. 11, 1997, \$29).

${ }^{434}$ Fedax NV v. Republic of Venezuela, ICSID, Case n. ARB/96/3, 9/3/1998, \$\$ 21-9.

435 Fedax NV v. Republic of Venezuela, ICSID, Case n. ARB/96/3, 9/3/1998, \$\$ 30-3.

${ }^{436}$ Fedax NV v. Republic of Venezuela, ICSID, Case n. ARB/96/3, 9/3/1998, \$\$ 42-3. 
Estado receptor. As decisões do ICSID não são vinculantes para casos futuros, então eles não constituem precedente estrito. No entanto, o caso Fedax pode exercer uma importante influência sobre o caso Abaclat, não só em aspectos jurisdicionais, mas também sobre o mérito, pois apenas uma minoria dos detentores de títulos italianos possui títulos de curto prazo. Como já foi observado anteriormente, a maioria dos títulos emitidos tem duração suficiente para ser compreendida como um investimento e não uma transação comercial normal, de acordo com o teste do caso Salini. Mas o caso Fedax manteve notável silêncio, no entanto, sobre uma questão importante levantada em Abaclat: ele não estabeleceu distinçôes entre as violações contratuais e de tratados, o que parece ser determinante para o sucesso das reivindicações dos detentores de títulos italianos. Foi mencionado acima que o Centro discutiu amplamente este tema, tendo em vista que reestruturaçoos de dívidas não são meramente quebras contratuais, pois o Estado usou seu poder para determinar certas condições da renegociação. Por exclusão, a reestruturação argentina não pode ser considerada meramente contratual, mas pode envolver a violação do BIT aplicável. Esta distinção foi negligenciada no caso Fedax.

Assim, o caso Fedax tem semelhanças com o caso Abaclat, principalmente quanto ao respeito dos contratos e à aplicação da noção de investimento para títulos soberanos. Mas não se deve esquecer que o caso Abaclat, além de rejeitar teste do caso Salini, introduziu uma distinção de violações contratuais e de tratados que não foram abordadas em Fedax. Assim, o papel inovador do caso Abaclat não deve ser desconsiderado.

A despeito de ainda estar distante de uma decisão quanto ao mérito, decido à complexidade da matéria e ao extenso número de credores, eventual decisão do ICSID favorável aos credores teria o potencial de reduzir fortemente a utilidade das cláusulas de ação coletiva e outras medidas destinadas a coordenar esforços de Estados e credores em direção a um acordo de reestruturação que solucione ou mitigue a crise de endividamento. Estender a proteção dos acordos bilaterais de investimento aos credores não participantes da negociação da dívida externa afetaria a percepção do risco nas decisões de investimentos, além de reduzir a flexibilidade das políticas adotadas diante do default ou de sua ameaça.

$O$ recurso à arbitragem internacional pode se tornar um caminho mais corriqueiro para a solução de disputas envolvendo títulos da dívida pública caso a decisão do caso Abaclat reconheça o direito dos credores ao integral pagamento. ${ }^{437} \mathrm{~A}$

437 O processo arbitral foi suspenso em 2011 após a solicitação argentina para descredenciar dois árbitros, mas o Centro decidiu voltar a se reunir em 2012 para discutir o caso. Isto foi 
proteção do investimento em títulos sob o acordo bilateral faria da arbitragem uma via jurídica atraente para confrontar as pretensōes do Estado que reestrutura sua dívida.

Apegando-se a esta possibilidade, os credores resistentes encontrariam em tribunais arbitrais internacionais, destacando-se o ICSID, o centro de gravidade de suas reclamações, em detrimento de outros credores e do Estado devedor, com a probabilidade de que os processos de reestruturação se tornassem ainda mais tumultuados. Com uma compreensão bastante ampla do que é um investimento internacional, a tendência é que se torne mais difícil obter acordos entre as diferentes partes para alterar as condições de pagamento dos títulos públicos, oferecendo-se a garantia do pagamento integral em cortes arbitrais e reduzindo, potencialmente, os incentivos para que se adira a uma oferta de reestruturação.

Reduzir o espaço das reações a um default da órbita de considerações econômicas objetivas e dos critérios políticos de negociação que valem para a ampla maioria dos credores aderentes, e ampliar os poderes da adjudicação, isso implicaria uma aplicação mais rígida de regras internacionais protetores do investidor estrangeiro. A este respeito, os BITs geralmente preveem restrições ao tratamento mais favorável a determinados Estados ou grupos de investidores, contendo cláusulas de nação mais favorecida. Isto significa que os investidores têm o direito de não ter um tratamento mais desfavorável do que aquele que o Estado oferece a uma terceira parte. Se dois Estados firmam um acordo com este princípio, e um deles participa de outro acordo com um terceiro Estado em que os investidores são tratados de forma mais benéfica, estes benefícios se estendem ao primeiro acordo.

Este é um aspecto relevante do problema porque há fundamentos razoáveis para que um Estado em crise estabeleça diferenças entre seus credores. ${ }^{438} \mathrm{~A}$ importância da dívida interna na composição da dívida do Estado, por exemplo, pode

interpretado como uma legitimação do processo (BEES UND CHROSTIN, Jessica. Sovereign Debt Restructuring and Mass Claims Arbitration before the ICSID. Harvard International Law Journal, Cambridge, v. 53, n. 2, 2012, p. 516).

${ }^{438}$ Há uma crescente literatura sobre o tema: PANIZZA, U. Is Domestic Debt the Answer to Debt Crisis?. In: HERMAN, B.; OCAMPO, J. A.; SPIEGEL, S. (Org.). Overcoming Developing Country Debt Crises. Nova Iorque: Oxford University Press, 2010; GORBUNOV, S. The Russian Federation: from Financial Pariah to State Reformer. In: HERMAN, B.; OCAMPO, J. A.; SPIEGEL, S. (Org.). Overcoming Developing Country Debt Crises. Nova Iorque: Oxford University Press, 2010; GELPERN, A.; SETSER, B. Domestic and External Debt: the Doomed Quest for Equal Treatment. Georgetown Journal of International Law, Washington, D.C., v. 35, n. 4, p. 795-814; FMI. Sovereign Debt Restructuring Mechanism Further Considerations. Washington, D.C.: FMI, 2002. 
justificar um tratamento diferenciado aos credores domésticos, aos quais se asseguraria prioridade perante credores externos. De um ponto de vista econômico, o pagamento da dívida externa transfere para fora do país recursos que poderiam se mostrar úteis para contornar a crise financeira, justificando medidas diferenciadas. Além disso, um país pode reestruturar sua dívida tendo em consideração a moeda em que ela foi emitida, como fez a Rússia quando preservou os eurotítulos do processo de redefinição dos pagamentos iniciados após a crise de $1998 .{ }^{439}$ Neste sentido, a aplicação do princípio da nação mais favorecida tal como ele é entendido para os investimentos estrangeiros não é um padrão adequado para a dívida pública. Questiona-se mesmo que isso seja necessário, pois muitos instrumentos de endividamento já contêm cláusulas de vedação de privilégios creditórios, que, dentro de determinadas condiçôes, constituem a promessa do Estado de que a ordem de pagamento dos credores seguirá critérios pré-estabelecidos - uma disposição comum na dinâmica dos mercados de títulos públicos. ${ }^{440} \mathrm{~A}$ este respeito, a abordagem até aqui conferida pelo ICSID às cláusulas da nação mais-favorecida não conferem, com clareza, proteção substancial aos investimentos. ${ }^{441}$

Ao desestimular a adesão de credores aos processos de reestruturação da dívida, é possível prever um incremento no número de disputas levadas aos tribunais arbitrais, tornando-se mais custoso para o Estado chegar a um consenso com os credores sobre as ofertas de pagamento, diminuindo o volume de recursos disponíveis para outras atividades. Da mesma forma, o equilíbrio entre os poderes de negociação em jogo seria alterado, com os processos de saída das crises ganhando uma camada adicional de complexidade, adiando a recuperação econômica e atrasando o retorno do país aos mercados financeiros. ${ }^{442} \mathrm{~A}$ depender de como o ICSID consolide os padrões de proteção dos detentores de títulos públicos, a distribuição dos riscos seria alterada ex post, de forma a potencialmente induzir os credores a assumir riscos excessivos.

439 GORBUNOV, S. The Russian Federation: from Financial Pariah to State Reformer. In: HERMAN, B.; OCAMPO, J. A.; SPIEGEL, S. (Org.). Overcoming Developing Country Debt Crises. Nova Iorque: Oxford University Press, 2010

${ }^{440}$ BUCHHEIT, L.; PAM, J. The Pari Passu Clause in Sovereign Debt Instruments. Emory Law 441

Journal, Atlanta, v. 53, s. n., 2004.

442 WAIBEL, M. Opening Pandora's Box: Sovereign Bonds in International Arbitration. The American Journal of International Law, Washington, D.C., v. 101, n. 4, 2007, p. 758. 


\subsubsection{A regulação judicial das renegociações da dívida pública}

As estratégias de renegociação da dívida pública não podem deixar de considerar a possibilidade de recurso à via judicial por aqueles credores que, minoritariamente, não aderiram às ofertas de reestruturação. A solução judicial que atenda a demandas relativas à inexecução da dívida pública de forma a determinar o cumprimento dos contratos segundo suas condiçôes judiciais, com pagamento imediato e integral, apresenta-se em relação dicotômica com os processos negociados de reescalonamentos e reduções dos valores devidos pelo Estado. Isto porque, para os credores privados que optam pela execução das obrigações financeiras segundo suas definições originais, não são oponíveis os termos do acordo de reestruturação, que é justamente a matéria que questionam por dele não terem participado. Há, no entanto, reflexos de decisões judiciais de tribunais internos sobre as renegociações da dívida pública conduzidas em âmbito internacional. O mais recente caso dos holdouts contra a Argentina deve ser interpretado à luz desta perspectiva, a de que há uma acentuada distinção entre ambos os modos de solução de controvérsias entre os credores e o Estado devedor. Se tanto a reestruturação facultativa quanto o acesso a um tribunal interno constituem, de forma mais ampla, métodos pacíficos, a solução jurisdicional se apresenta, entretanto, como a mais conflitiva. ${ }^{443}$

A "corrida às cortes" é apresentada como uma forma de externalidade negativa nas renegociações da dívida pública e consiste na litigância iniciada por determinados credores com o propósito de recuperar a totalidade de seus créditos. ${ }^{444}$ Caso obtenham sucesso em executar bens do Estado devedor localizados no exterior de forma a assegurar o cumprimento de decisões que o condenem ao pagamento integral das obrigações, os efeitos ultrapassam os interesses exclusivos das partes processuais. Para os credores concordantes com as reestruturações, os encargos do adimplemento imediato das obrigações aos minoritários resistentes significa o aumento dos riscos de crédito sobre os pagamentos consensualmente modificados com uma maioria aderente. ${ }^{445}$ Se os regimes falimentares privados preveem critérios

443 Como a ela se refere ROBERT, E. Rééchelonnement de la Dette ou Règlement Judiciaire? Analyse de la Jurisprudence Interne et Internationale au Regard des Enjeux de la Renégociation de la Dette. In: CARREAU, D.; SHAW, M. (Coord.). La Dette Extérieure. Haia: Martinus Nijhoff Publishers, 1995, p. 609.

${ }^{444}$ Segundo B. Barnett, S. Galvis e G. Gouraige, as consequências de litígios promovidos individualmente seriam ainda piores do que aquelas eventualmente feitas por todo o grupo de credores, "possibily precipitating an avalanche of litigation and hampering coordinated attempts at recovery or renegotation of the debt" (On Third World Debt. Harvard International Law Journal, Cambrdige, vol. 25, n. 2, 1984, p. 113).

445 Ver ROUBINI, N. Do We Need a New Bankruptcy Regime?. Brookings Papers on Economic Activity, Washington, D.C., n. 1, 2002, p. 322-3. 
de organização do acesso aos bens do devedor, a corrida para competitivamente alcançar o patrimônio público, descrita por Sachs como a grab race emergente em um cenário desregulamentado, pode, ainda, diminuir o valor dos ativos do Estado em moratória. ${ }^{446}$

Uma questão da maior relevância sobre a atuação dos tribunais nacionais em situações de repercussão internacional é, então, a lei aplicável, que determinará o foro competente. Os contratos internacionais mais significativos frequentemente contêm cláusula de eleição de foro que especifica as normas aplicáveis pela instância decisória escolhida, o que tem grande relevância no contexto internacional em obrigaçôes marcadas por elementos de estraneidade. ${ }^{447}$ Em razão da importância da cidade de Nova Iorque nos mercados financeiros, as operaçôes financeiras ali emitidas ficam tipicamente sujeitas a seu direito e a sua jurisdição, mesmo que muitas dessas operaçóes tenham pouco envolvimento com aquele território além de sua emissão.

Uma das razões para esta escolha é a experiência daqueles tribunais com matérias relativas a dívida pública, e as cortes de Nova Iorque são interpretadas como uma base neutra capaz de conduzir os processos judiciais segundo um corpo estável e previsível de normas comerciais. ${ }^{448}$ Algo semelhante acontece com os tribunais ingleses, cuja independência e objetividade na análise de assuntos financeiros também situam aquele corpo de normas como opção tida por confiável nas transações comerciais e, por isso mesmo, um sistema jurídico familiar aos credores internacionais. ${ }^{449}$ Quando se opta pelo foro de Nova Iorque ou do Reino Unido para a solução

446 SACHS, J. Resolving the Debt Crisis of Low-Income Countries. Brookings Papers on Economic Activity, Washington, D.C., n. 1, 2002, p. 2.

447 Sobre aspectos mais gerais, cf. STEINER, H.; VAGTS, D. Transnational Legal Problems. Nova Iorque: The Foundation Press, 1976, p. 91.

448 "Considering New York City's status as a leading international banking and trading centre, parties to na international agreement, eventhough having little or no connection with New York, often agree to submit to the laws and jurisdiction of New York. The reason is the ample experience of New York courts in dealing with these matters; New York is viewed as a dorum that, on a neutral basis, could manage a stable and sophisticated body of commercial law" (CARRILLO-BATALLA, V. Conflicts of Laws in International Lending Transactions: Governing Law and Choice of Forum. In: CARREAU, D.; SHAW, M. (Coord.). La Dette Extérieure. Haia: Martinus Nijhoff Publishers, 1995, p. 422).

449 "English law is often chosen because it provides a system of law which is sufficiently independent in the approach of its legal profession and judicature to give both borrowers and lenders confidence. (...) As a result of such factors, English law is a system of law with which international lenders have become familiar, avoiding the necessikty of a detailed investigation by the lenders into the relevant provisions of an unfamiliar system" (CATES, A.; ISERN-FELIU, S. 
de controvérsias contratuais, faz-se também a opção por sistemas mais previsíveis em razão de uma certa prática consolidada, e se evitam, assim, os custos de investigação sobre o funcionamento de sistemas jurídicos cujas tendências são menos conhecidas. A preferência entre os credores é, portanto, pela eleição de algum desses foros, o que permite afirmar que não apenas o campo material em que já se manifestaram decisões sobre dívida pública é razoavelmente escasso em comparação com outras matérias, mas também suas fontes judiciais domésticas são bastante concentradas. $\mathrm{O}$ que sobressai do conjunto é a jurisprudência dos tribunais de Nova Iorque como corpo de referência jurisprudencial principal, seguida dos tribunais ingleses, em razão de sua importância como centros financeiros internacionais. ${ }^{450}$

A opção pela aplicabilidade destes sistemas jurídicos para a solução de disputas contratuais, se hoje tem se disseminado, encontrava algumas barreiras a partir da posição de Estados devedores que os consideravam demasiadamente associados aos interesses dos credores. Muitos países tradicionalmente se opunham à aplicação do direito de um Estado credor ou protetor de nacionais credores, mas passaram a rever esta posição principalmente depois da década de 1970, quando houve maior demanda por capital estrangeiro. Nesta categoria estão os países da América Latina, que tipicamente submetiam as obrigaçōes financeiras à lei do Estado devedor, o que significava dizer a seu direito doméstico, como consequência da aplicação da Doutrina Calvo. Segundo esta doutrina, é vedado a um Estado tratar estrangeiros de forma diferente de seus nacionais, o que significa concretamente, para os contratos internacionais, que operações financeiras externas do Estado não podem estar sujeitas a lei diferente daquela aplicável às operaçôes internas. Desse modo se consolidou certa prática, atualmente revista, de aplicar o direito interno às obrigaçõos constitutivas da dívida externa. A partir da maior presença do capital estrangeiro, no entanto, esta posição foi mitigada em favor da aplicação do direito estrangeiro para obrigações perante instituições internacionais e bancos

Choice of Law and Site of Litigation in England. In: GRUSON, M.; REISNER, R. Sovereign Lending: Managing Legal Risk. Londres: Euromoney Publications, 1984, p. 71).

450 “(...) non seulement la jurisprudence relative au rééchelonnement de la dette est limitée, mais elle est essentiellement américaine, et de surcroît new-yorkaise. L'origine peut en être largement attribuée à l'importance de New York comme place financière international et le renvoi quasi systématique dans les contrats de prêts et d'emprunts aux jurisdictions de l'Etat de New York, les jurisdictions anglaises venant en seconde position" (ROBERT, E. Rééchelonnement de la Dette ou Règlement Judiciaire?: Analyse de la Jurisprudence Interne et Internationale au Regard des Enjeux de la Renégociation de la Dette. In: CARREAU, D.; SHAW, M. (Coord.). La Dette Extérieure. Haia: Martinus Nijhoff Publishers, 1995, p. 621). 
comerciais. ${ }^{451}$ Esta perspectiva mais flexível foi corroborada pela Convenção Interamericana sobre Direito Aplicável aos Contratos Internacionais, cujo artigo $7^{\circ}$ define que o contrato rege-se pelo direito escolhido pelas partes. ${ }^{452}$

A nova conjuntura econômica internacional, com a presença maciça dos títulos públicos como instrumento de concessão de empréstimos aos países em desenvolvimento encontraria bases jurídicas mais estáveis se disciplinadas por normas já familiares a estes credores em particular, tais como o direito do estado de Nova Iorque, cuja corte federal já havia se pronunciado a respeito de reescalonamentos da dívida pública no caso Allied Bank, de $1985 .{ }^{453}$ Este caso ilustra como um credor individual pode interferir e redefinir pagamentos negociados entre o Estado e os demais credores, e expõe as divergências estratégicas entre os grupos de credores que perseguem as renegociações e aquelas que optam pela solução judicial.

No caso mencionado, em agosto de 1981 o governo da Costa Rica, em razão de grave crise econômica, instituiu controles de transferência de capitais a título de pagamentos de juros ou amortização das dívidas contraídas em face de credores estrangeiros. Em novembro do mesmo ano o país iniciaria a negociação da dívida externa, o que afetou os pagamentos da dívida pública, incluindo as obrigações face a um consórcio bancário que agrupava trinta e nove membros. Os bancos sindicados postularam, na Corte Federal de Nova Iorque, o pagamento integral do principal e dos juros dos bilhetes que portavam, mas foi decidido, então, que uma decisão favorável obrigaria à realização de pagamentos em sentido contrário à determinação do governo costa-riquenho, o que poderia interferir até mesmo nas relaçōes diplomáticas do governo americano com aquele país. ${ }^{454}$ Após o início das negociações, estes bancos chegaram a um acordo, com exceção de um, o Fidelity

451 MEGLIANI, M. Sovereign Debt: Genesis, Restructuring, Litigation. Heidelberg: Springer, 2015, p. 193-196.

452 Convenção Inter-Americana sobre Direito Aplicável aos Contratos Internacionais, de $17 / 3 / 1994$.

453 Há decisões relativas a diversos processos com o consórcio Allied Bank, mas a principal delas é a decisão final, referida como Allied Bank v. Banco Credito Agrícola de Cartago, United States Court of Appeals, Second Circuit, 18/3/1985. Ver também ROGOFF, K.; ZETTELMEYER, J. Bankruptcy Procedures for Sovereigns: a History of Ideas, 1976-2001. IMF Staff Papers, Washington, D.C., v. 49, n. 3, 2002, p. 475.

${ }^{454}$ No original, "[a] judgment in favor of Allied in this case would constitute a judicial determination that defendants must make payments contrary to the directives of their government. (...) Such na act by this court risks embarrassment to the relations between the Executive Branch of the United States and the Government of Costa Rica" (Allied Bank v. Banco Credito Agricola de Cartago, United States District Court, Second District, 8/7/1983, p. 566). 
Union Trust of New Jersey, representado pelo banco Allied Bank. Sobre a resistência deste único banco, decidiu a Corte que "enquanto as partes podem concordar em renegociar as condiçóes de pagamento, a obrigação de pagar subjacente permanece válida e executável" ${ }^{455}$ Ao afirmar que as proteções aos devedores garantidas pelo Capítulo 11 do Código Falimentar dos Estados Unidos (US Bankruptcy Code) não se aplicam a Estados nacionais, a decisão do Tribunal foi ainda além: "a tentativa unilateral do governo da Costa Rica de repudiar obrigaçôes privadas e comerciais é inconsistente com a resolução ordenada dos problemas internacionais da dívida". 456

A manifestação jurisdicional local de Nova Iorque deixou, neste caso, de esclarecer como permitir a livre atuação do credor resistente para barganhar sua adesão contribuiria para a resolução ordenada dos problemas internacionais da dívida, expondo como decisões nacionais, no âmbito da competência jurisdicional de cada Estado, podem estimular a ação descoordenada entre os credores, conferindo respaldo ao comportamento que exacerba as dificuldades de uma ação articulada. O critério decisório, no entanto, pode ser identificado com o princípio da relatividade dos contratos, cujos efeitos se estendem aos credores que voluntariamente consentiram com a novação contratual, e não aos terceiros não aderentes. Neste sentido, a decisão do caso Allied Bank é fundamental ao afirmar os direitos dos credores e a recusar a interferência do Estado sobre o equilíbrio contratual por via de uma declaração de moratória. ${ }^{457} \mathrm{E}$, assim, que é do interesse americano a garantia de pagamento nos Estados Unidos em dólares americanos dos contratos sujeitos à jurisdição dos Estados Unidos, de acordo com princípios do direito contratual. ${ }^{458}$

455 Allied Bank v. Banco Credito Agrícola de Cartago, United States Court of Appeals, Second Circuit, 18/3/1985, p. 519. No original, "[w] hile parties may agree to renegotiate conditions of payment, the underlying obligations to pay nevertheless remain valid and enforceable".

456 Allied Bank v. Banco Credito Agrícola de Cartago, United States Court of Appeals, Second Circuit, 18/3/1985, p. 522. No original, "[t] he Costa Rican government's unilateral attempt to repudiate private, commercial obligations is inconsistent with the orderly resolution of international debt problems".

457 Sobre os critérios das decisōes da Corte Federal de Nova Iorque, no caso Allied Bank e outros, cf. ROBERT, E. Rééchelonnement de la Dette ou Règlement Judiciaire? Analyse de la Jurisprudence Interne et Internationale au Regard des Enjeux de la Renégociation de la Dette. In: CARREAU, D.; SHAW, M. (Coord.). La Dette Extérieure. Haia: Martinus Nijhoff Publishers, 1995 , p. 619.

458 "The United States has an interest in ensuring that creditors entitled to payment in the United States in United States dollars under contracts subject to the jurisdiction of the United States courts may assume that, except under the most extraordinary circumstances, their rights Will be determined in accordance with principles of contract law" (Allied Bank v. Banco Credito Agrícola de Cartago, United States Court of Appeals, Second Circuit, 18/3/1985, p. 767). 
No período concomitante e posterior à crise argentina, a litigância judicial de credores resistentes a propostas de reestruturação reavivou o problema dos holdouts, cujo comportamento pode induzir a rupturas nos processos de renegociação. ${ }^{459} \mathrm{No}$ caso NML Capital, o resíduo de credores que não consentiram com as últimas propostas de reestruturação, entre os quais o hedge fund NML Capital, provocou as instâncias judiciais de Nova Iorque, foro competente para os títulos que haviam adquirido, a se pronunciar sobre a reestruturação argentina. A primeira decisão mais relevante a esse respeito data de dezembro de 2011, que proibiu a Argentina de promover qualquer forma de discriminação dos holdouts em favor daqueles que haviam aceitado as propostas de reestruturação. ${ }^{460}$ Colocadas em termos de alguma violação da igualdade entre todos os credores, a existência de pelo menos um credor resistente às propostas de reestruturação demonstra a diferença de tratamento sistemático entre as instâncias multilaterais de renegociação, cujo objetivo é chegar a algum consenso majoritário sobre as modificações das condições de pagamento das obrigaçôes financeiras, e a solução judicial neste caso, que desestimula a formação deste consenso ao reconhecer o direito ao recebimento integral da parte de alguns credores. Da mesma forma, decisão de 2012 proibira a Argentina de realizar pagamentos da dívida reestruturada sem que pagasse concomitantemente os portadores de títulos antigos. ${ }^{461} \mathrm{Em}$ análise das reservas internacionais da argentina, a Corte de Nova Iorque chegou mesmo a afirmar que esta determinação não comprometeria a situação econômica do país, pois teria capacidade de pagamento. ${ }^{462} \mathrm{O}$ juiz Griesa, responsável pelo caso, chegou também a determinar que estes pagamentos se realizassem rapidamente, pois, em razão das declarações inflamadas da presidente da Argentina, que afirmava categoricamente que descumpriria a ordem judicial, procurava-se tomar precauçôes diante da possibilidade de que seu governo se evadisse do cumprimento da sentença, que determinava o pagamento integral dos títulos. ${ }^{463}$

459 BRATTON, W.; GULATI, G. Sovereign Debt Restructuring and the Best Interest of Creditors. Vanderbildt Law Review, Nashville, vol. 57, n. 1, 2004.

${ }^{460}$ NML Capital, Ltd. v. Republic of Argentina, United States Court of Appeals, Second Circuit, 7/12/2011, p. 2.

461 NML Capital, Ltd. v. Republic of Argentina.,,United States Court of Appeals, Third Circuit, 26/10/2012, p. 254.

${ }^{462}$ NML Capital, Ltd. v. Republic of Argentina,. United States Court of Appeals, Third Circuit, 26/10/2012, p. 263-264.

463 Foi usado, então, a expressão ratable payment, que significa o pagamento de todos os credores em proporções definidas conforme a importância de sua participação nos empréstimos originalmente conferidos. Cf. NML Capital, Ltd. v. Republic of Argentina,, United States Court of Appeals, Third Circuit, 21/11/2012, p. 10. 
A decisão foi tomada segundo uma racionalidade distinta daquela perseguida nas renegociações entre devedores e credores, ${ }^{464}$ ainda que não seja o caso de afirmar que o teor significativo de um destes dois aspectos seja exclusivamente positivo e o outro exclusivamente negativo. Trata-se menos de uma afirmação do mérito intrínseco e mais da constatação de uma tensão entre ambos os métodos de solução de controvérsias. Alguns autores apontaram vantagens da solução pela via judicial. Considerando-se que o fazem em vista de características peculiares ao caso, isto não chega a comprometer a relação colidente em que se colocam as renegociações por procedimentos multilaterais e a decisão por tribunais externos a este campo de atuação, em seus aspectos gerais. No caso em questão, há elementos controversos a respeito da conduta do governo argentino ao longo das duas ofertas mais recentes de sua reestruturação, a qual, apesar de obter a adesão de uma ampla maioria na fase final, não se resolveu sem que os negociadores fossem acusados de não promover a cooperação entre os diferentes credores. Entre estes se disseminavam, de fato, muitas dúvidas sobre a situação financeira do país e, consequentemente, situavam-se em uma nebulosa zona de conhecimento sobre sua real capacidade de pagamento. ${ }^{465}$ Daí que se pudesse justificar a não adesão às ofertas de conversão dos títulos como uma divergência ponderada sobre a boa-fé do devedor que alegava a proximidade da insolvência. De modo mais abstrato se poderia também dizer que nem todos os efeitos da solução pela via judicial são problemáticos, pois ela serviria de contrapeso, em benefício dos direitos dos credores, às declarações oportunistas de moratórias e eventuais comportamentos colusivos de uma maioria de credores que se agrupassem em detrimentos dos interesses de uma minoria que, sem o acesso aos tribunais, fossem eles domésticos ou internacionais pela via arbitral, ficaria indefesa. ${ }^{466}$

${ }^{464}$ Para a análise da decisão conforme o direito interno norte-americano, cf. MUSE-FISHER, J. Starving the Vultures: NML Capital v. Republic of Argentina and Solutions to the Problem of Distressed-Debt Funds. California Law Review, Berkeley, vol. 102, n. 6, dez. 2014.

465 Segundo Porzecanski, maior instabilidade aos mercados financeiros globais se originaria não do comportamento de credores oportunistas, mas de devedores oportunistas que não são transparentes a respeito do estado de sua capacidade de pagamento. Assim, "[t] he case of Argentina suggests that much of the academic and policy making literature has ignored the realistic possibility that rogue sovereign debtors, rather than rogue private creditors, are the ones that pose the greatest threat to the integrity and efficiency of the international financial architecture(cf. PORZECANSKI, A. C. From Rogue Creditors do Rogue Debtors: Implications of Argentina's Default. Chicago Journal of International Law, Chicago, vol. 6, n. 1, jan. 2005, p. 331).

${ }^{466}$ Como descrito em FISCH, J. Vultures or Vanguards? the Role of Litigation in Sovereign Debt Restructuring. Faculty Scholarship, Pensilvânia, n. 1051, 2004, p. 1051. 
A despeito destas ponderações, as preocupações com a atuação competitiva de grupos minoritários de credores são um problema recorrente das reestruturações da dívida mobiliária em razão da ausência de mecanismos aptos a contrabalançar os efeitos de decisões judiciais favoráveis que se contraponham ao resultado das renegociaçōes internacionais. Isolados algumas particularidades, pode-se apontar a disputa entre métodos de solução de controvérsias como uma oposição entre arranjos institucionais de funcionamento diverso. Quando se buscam referências jurisprudenciais a respeito da dívida pública, é inevitável recorrer a categorias normativas aplicadas pelo direito de Nova Iorque, o que, por si, demonstra a escassez de tratamento normativo mais abrangente.

Sob a perspectiva desta ordem jurídica, competiria ao Estado devedor operar a partir de categorias normativas próprias do direito nova-iorquino para que, a partir dos meios de defesa à sua disposição, argumentasse pelos efeitos de uma decisão judicial desfavorável sobre as perspectivas econômicas negociadas com um grupo majoritário de credores. Os meios de defesa do Estado devedor são aqueles propriamente judiciais, fundados na lei interna do foro competente, e escapam, portanto, à lógica das negociações conduzidas frente ao FMI e aos Clubes de Londres e Paris. Os principais meios de defesa dos credores, no sistema nova-iorquino, são a invocação da doutrina do ato de Estado (Act of State) e, relacionada a ela, o reconhecimento de efeitos jurídicos para a cortesia internacional (comity), na forma interpretada pelos referidos tribunais. A eficácia destes argumentos, fundada na jurisprudência local, se mostrou, contudo, falha ao longo do tempo.

De um lado, a doutrina do Act of State se fundamenta em antiga decisão da Suprema Corte dos Estados Unidos, o caso Underhill v. Hernandez, que reconheceu o princípio da igualdade entre os Estados, ${ }^{467}$ e consiste na impossibilidade de apreciação judicial, por um tribunal americano, de decisões tomadas por um governo estrangeiro em seu próprio território. A doutrina foi invocada no caso Allied Bank para que a primeira instância recusasse seguimento ao pedido formulado pelos credores do governo da Costa Rica. ${ }^{468} \mathrm{Se}$ em casos que se referem a expropriações de bens estrangeiros, levados à apreciação de um juiz de Nova Iorque, o elemento territorial enfrenta menores dificuldades de apreciação porque os bens

467 "Every sovereign State is bound to respect the independence of every other sovereign State, and the courts of one country will not sit in judgment on the act of the government of another done within its own territory. Redress of grievances by reason of such acts must be obtained through the means open to be availed of by sovereign powers as between themselves" (Underhill v. Hernandez, United States Supreme Court, 29/11/1897, p. 168.

468 Ver 468 supra. 
nacionalizados têm natureza geralmente material, a determinação do local da expropriação da dívida pública é tema mais complexo. O crédito é um bem intangível, o que levanta diversas questões práticas sobre o local de situação da dívida e, mais precisamente, sobre o local de sua inexecução. Este seria aquele onde se decidiu a suspensão do pagamento ou onde a dívida foi emitida? Em segunda decisão no caso Allied Bank, a corte recursal modificou o entendimento da primeira instância em favor de uma interpretação que considerava Nova Iorque, onde as dívidas foram emitidas, como o local de inexecução das obrigações financeiras, e não o território costa-riquenho, onde se declarara a suspensão. Assim, afastou-se a doutrina do Act of State inicialmente afirmada, pois, apesar de se tratar de uma decisão de governo estrangeiro, os efeitos teriam se dado em Nova Iorque. Aí se começou a precisar a noção do situs da dívida pública no direito nova-iorquino, aplicando-se o critério da possibilidade de que o Estado de origem exercesse completamente suas competências soberanas sobre o ato (complete fruition within the dominion of the government). ${ }^{469}$ A Costa Rica teria domínio e controle sobre a dívida perante o banco estrangeiro apenas se pudesse pagar as obrigações em dólar. Como aquele governo não poderia extinguir as obrigações com seus bancos nacionais para adimplir as obrigações com o banco estrangeiro, considerou-se que não estava em condições de pleno domínio sobre a sua dívida. Além disso, como o local de pagamento, a moeda, o foro de opção e o domínio do representante do consórcio bancário eram a cidade de Nova Iorque, a jurisdição potencial da Costa Rica não foi suficiente para que se situasse o local de inexecução das dívidas por ela tomada em seu próprio território. ${ }^{470}$

Se a doutrina do ato de Estado não constituiu suficiente meio de defesa do Estado devedor, restaria ainda a invocação da cortesia internacional, como se tentou ainda no caso Allied Bank. A comity permitiria que se reconhecessem a validade e os efeitos dos atos de um Estado estrangeiro sobre território americano desde que esses atos fossem conformes ao direito e às políticas dos Estados Unidos. ${ }^{471}$ Admite-se, assim, que a política externa do governo americano influencie o exercício do

469 Allied Bank v. Banco Credito Agrícola de Cartago, United States Court of Appeals, Second Circuit, 18/3/1985, p. 767.

470 Allied Bank v. Banco Credito Agrícola de Cartago, United States Court of Appeals, Second Circuit, 18/3/1985, p. 767.

471 ROBERT, E. Rééchelonnement de la Dette ou Règlement Judiciaire?: Analyse de la Jurisprudence Interne et Internationale au Regard des Enjeux de la Renégociation de la Dette. In: CARREAU, D.; SHAW, M. (Coord.). La Dette Extérieure. Haia: Martinus Nijhoff Publishers, 1995, p. 640-641. 
poder jurisdicional. Sob o fundamento de que uma decisão favorável aos credores bancários comprometeria as relações entre Estados Unidos e Costa Rica, a primeira decisão do caso Allied Bank admitira a conformidade da moratória costa-riquenha às políticas norte-americanas. Esta posição se havia baseado em indícios que apontavam para a participação do governo dos Estados Unidos na renegociação das dívidas latino-americanas durante as crises da década de $1980 .{ }^{472}$ Houve, aqui, alguma forma de comunicação entre os acordos do Clube de Paris e a Corte Federal de Nova Iorque, que considerou que a moratória costa-riquenha era compatível com as políticas e o direito dos Estados Unidos a partir da ratificação que este país conferira às renegociações. A reconhecimento jurídico da cortesia internacional permitiria que, desta forma, acordos firmados em renegociaçóes multilaterais condicionassem manifestaçōes jurisdicionais domésticas. No caso Allied Bank, no entanto, a atuação do governo dos Estados Unidos como amicus curiae esclareceu que a ratificação dos acordos do Clube de Paris, como não poderia deixar de ser, se referiam à dívida intergovernamental, e não às obrigaçooes comerciais contestadas no caso. ${ }^{473}$

A ausência de procedimentos organizados para as modificações dos termos originais dos títulos públicos expôs, neste caso, os limites da comity como meio de defesa dos Estados devedores, em razão de ter sido possível demonstrar apenas a compatibilidade da moratória de Costa Rica com as políticas dos Estados Unidos para a dívida bilateral, formalizada em documentos internacionais, mas não quanto à dívida privada expressa em títulos. Diante deste cenário fragmentado entre sentidos colidentes da ação de instituições internacionais que operam pela via negocial e outras instâncias, internas e internacionais, que se valem de critérios normativos próprios sem evidentes relações com o espaço de ação das decisões economias e políticas das renegociações, alguns cenários se delineiam a respeito de como conferir às soluções de controvérsias sobre a inexecução da dívida externa (particularmente da dívida mobiliária) um caráter mais ordenado e sistemático, ou ao menos com menores sinais de fragmentação.

472 Entre algumas destas medidas de participação, o incentivo do governo Reagan ao Foreign Assistance Act, que autorizava a continuidade dos empréstimos à Costa Rica (Allied Bank v. Banco Credito Agrícola de Cartago, United States Court of Appeals, Second Circuit, 18/3/1985, p. 745).

473 Allied Bank v. Banco Credito Agrícola de Cartago, United States Court of Appeals, Second Circuit, 18/3/1985, p. 742-7. 
